\title{
Synthesis, Structure, and Biological Assays of Novel Trifluoromethyldiazepine-Metal Complexes
}

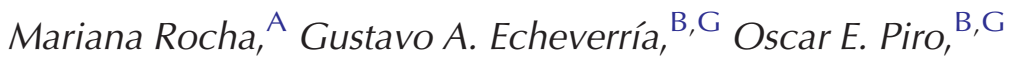 \\ Jorge J. Jios, iD C Rocío D. I. Molina, ${ }^{\mathrm{D}}$ Mario E. Arena, ${ }^{\mathrm{D}, \mathrm{G}}$ \\ Sonia E. Ulic, ${ }^{\mathrm{E}, \mathrm{F}, \mathrm{G}}$ and Diego M. Gil ${ }^{\mathrm{A}, \mathrm{G}, \mathrm{H}}$ \\ AINQUINOA (CONICET - UNT), Instituto de Química Orgánica, Facultad de \\ Bioquímica, Química y Farmacia, Universidad Nacional de Tucumán, Ayacucho 471, \\ T4000INI, San Miguel de Tucumán, Argentina. \\ ${ }^{B}$ Departamento de Física, Facultad de Ciencias Exactas, Universidad Nacional de La \\ Plata e IFLP (CONICET, CCT-La Plata), CC 67, 1900, La Plata, Argentina. \\ C UNIDAD PLAPIMU-LASEISIC (UNLP-CIC), Departamento de Química, Facultad de \\ Ciencias Exactas, Universidad Nacional de La Plata, 47 esq. 115, 1900, La Plata, \\ Argentina. \\ DINBIOFAL (Instituto de Biotecnología Farmacéutica y Alimentaria)-CONICET y \\ Facultad de Bioquímica, Química y Farmacia, Universidad Nacional de Tucumán \\ (UNT), Avenida Kirchner 1900, Tucumán, 4000, Argentina. \\ ${ }^{\mathrm{E}}$ CEQUINOR (CONICET-UNLP), Facultad de Ciencias Exactas, Universidad Nacional \\ de la Plata, Bv. 120 № 1465, 1900, La Plata, Argentina. \\ F Departamento de Ciencias Básicas, Universidad Nacional de Luján, Rutas 5 y 7, 6700, \\ Luján, Buenos Aires, Argentina. \\ $\mathrm{G}_{\text {Members of the research Career of CONICET. }}$ \\ ${ }^{\mathrm{H}}$ Corresponding author. Email: dmgil@fbqf.unt.edu.ar
}

\begin{abstract}
A new series of $\mathrm{Cu}^{\mathrm{II}}, \mathrm{Ni}^{\mathrm{II}}, \mathrm{Co}^{\mathrm{II}}$, and $\mathrm{Mn}^{\mathrm{III}}$ complexes have been synthesised from the (6Z)-6-(7-trifluoromethyl-1,2,3,4tetrahydro-5H-1,4-diazepin-5-ylidene)cyclohexa-2,4-dien-1-one (HDZP) ligand. These complexes were characterised by elemental, spectroscopic (IR and UV-vis), and thermal analysis. The crystal structure of Cu-DZP was solved by X-ray diffraction methods. The complex crystallises in the monoclinic $P 2_{1} / c$ space group, with two molecules per unit cell. The crystal lattice is stabilised by different intra and intermolecular interactions. Hirshfeld surface analysis was employed to obtain additional information about interactions that are responsible for the crystal packing. Quantitative examination of the fingerprint plots indicated the dominant contribution of $\mathrm{H} \cdots \mathrm{H}$ and $\mathrm{H} \cdots \mathrm{X}(\mathrm{X}=\mathrm{O}, \mathrm{F})$ interactions in the crystal packing. In addition, $\mathrm{C}-\mathrm{H} \cdots$ chelate ring $(\mathrm{CR})$ and $\mathrm{C}-\mathrm{H} \cdots \pi$ interactions are described in detail and evaluated using DFT calculations. The antibacterial properties and the mechanism of inhibition of the main bacterial resistant mechanism, the biofilm, of the metal complexes and free ligand were investigated. [Mn(DZP $\left.)_{3}\right] \cdot 2 \mathrm{H}_{2} \mathrm{O}$ was the most active complex against the Pseudomonas aeruginosa biofilm formation with an inhibition of $40 \%$. However, none of the complexes inhibit more than $25 \%$ of the Gram negative bacteria microbial development. The most meaningful result was the bactericidal effect of $\left[\mathrm{Co}(\mathrm{DZP})_{2}\left(\mathrm{H}_{2} \mathrm{O}\right)_{2}\right] \cdot 2 \mathrm{H}_{2} \mathrm{O}$ against the Gram positive bacteria, Staphylococcus aureus, which inhibits the bacterial development and significantly reduces the biofilm formation at low concentration.
\end{abstract}

Manuscript received: 27 July 2019.

Manuscript accepted: 20 November 2019.

Published online: 20 December 2019.

\section{Introduction}

Diazepines (DZPs) and their derivatives are nitrogen-containing heterocyclic compounds which show relevant biological properties and numerous applications in medicinal chemistry. It is well known that 1,4-diazepine heterocyclic compounds such as Zometapine, Etizolam, Brotizolam, Clozapine, Dibenzepine, and Diazepam ${ }^{[1-3]}$ show a wide range of biological activities being active in the treatment of insomnia, ${ }^{[4]}$ epilepsy, and alcoholism. ${ }^{[5]}$ In recent decades, numerous structural modifications on the diazepine core have been performed in order to expand their biological activities including antibacterial, ${ }^{[6,7]}$ antioxidant, ${ }^{[8]}$ antiviral, ${ }^{[9]}$ anticonvulsant, ${ }^{[10]}$ and antitumour ${ }^{[11]}$ properties. In addition, herbicide and anti-HIV activities have been also reported. ${ }^{[12,13]}$ Generally, DZP derivatives with seven-membered rings are synthesised by a cyclocondensation process with a high regioselectivity. Moreover, DZPs are widely 


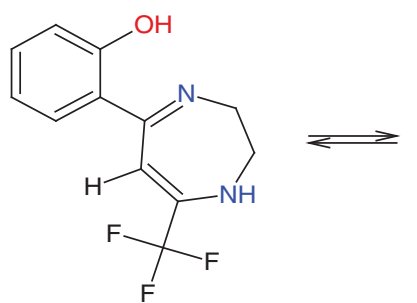

Enol-imine form I

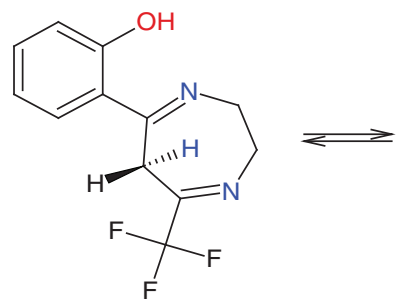

Enol-imine form II<smiles>O=C1C=CC=CC1=C1C=C(C(F)(F)F)NCCN1</smiles>

Keto-enamine form

Scheme 1. Different tautomeric forms of HDZP

used as synthons for the synthesis of triazole and oxadiazole derivatives. ${ }^{[14-16]}$ In the last years, the dependence on the stereochemistry of the seven-membered DZP ring derivatives with biological activity have attracted remarkable interest. ${ }^{[17]}$ The different tautomeric forms of 1,4-DZPs were studied by different experimental techniques such as X-ray diffraction (XRD), nuclear magnetic resonance (NMR), UV-visible spectroscopy, and theoretical calculations. From these studies, it can be concluded that the chair form of the DZP ring is the most stable conformation, although the rapid inter-conversion involving the boat-shape form was also studied by NMR spectroscopy for the DZP ring in 1,4-DZP derivatives and related benzodiazepines. ${ }^{[18]}$ The introduction of the $-\mathrm{CF}_{3}$ group allowed improvement of both the physicochemical and biological properties of the host compounds, as described in related trifluoromethyl chromones. ${ }^{[19]}$

Metal complexes have been widely used in pharmacology and medicinal chemistry for the treatment of many diseases. The interaction between DZP derivatives and metal ions to form metal-based drugs has been investigated by some groups. ${ }^{[20]}$ Generally, 1,4-DZP can act as a monodentate ligand coordinating through its $\mathrm{N}$ atom, ${ }^{[20,21]}$ but in some cases as a bridging ligand. ${ }^{[22]}$ Romba and co-workers have reported the structural features of a new tridentate ligand 1,4-diazepan-6-amine and a complete study of the structural and spectroscopic characterisation of $\mathrm{Cu}^{\mathrm{II}}, \mathrm{Ni}^{\mathrm{II}}$, and $\mathrm{Zn}^{\mathrm{II}}$ metal complexes has been performed. ${ }^{[23]}$ The inclusion of metal ions into DZP structures can induce changes in the pharmacological properties of the ligand. The use of metal ions in the synthesis of new antibacterial compounds is related to the different mechanism of action that they can present, which is different from the organic ligand, and which generally possess a single molecular target. ${ }^{[24]}$ For example, $\mathrm{Cu}^{\mathrm{II}}$ ions can damage cellular membranes in bacteria in order to interact with DNA, causing bacterial death. ${ }^{[24]}$ In addition, some 1,4-DZP derivatives were found to be highly selective and sensitive chemosensors for $\mathrm{Cu}^{\mathrm{II}}$ distinguishing it from other cations. ${ }^{[25]}$

Non-covalent interactions involving $\pi$-systems are relevant in the field of supramolecular chemistry, crystal engineering, and in the study of crystal packing of molecules. In general, organic molecules with planar geometry participate in $\mathrm{C}-\mathrm{H} \cdots \pi$ and $\pi$-stacking interactions. In addition, other planar moieties can also participate in 'un-conventional' or 'non-classical' $\mathrm{C}-\mathrm{H} \cdots \pi$ and $\pi \cdots \pi$ contacts. It is well documented that planar chelate rings $(\mathrm{CR})$ with delocalised $\pi$-bonds participate in $\pi$-stacking interactions analogous to those of aromatic molecules in transition metal complexes. Recent investigations have suggested that these types of interactions are responsible in the stabilisation of inorganic and hybrid metal-organic compounds. ${ }^{[26-29]}$ In this work we have demonstrated the relevance of $\mathrm{C}-\mathrm{H} \cdots \pi(\mathrm{CR})$ in the crystal packing of the $\left[\mathrm{Cu}(\mathrm{DZP})_{2}\right] \cdot 2 \mathrm{H}_{2} \mathrm{O}$ metal complex.

Biofilms are communities of microorganisms that inhabit a self-produced biopolymer. In this environment, antimicrobial resistance is superior to free-living bacteria. ${ }^{[30]}$ The biofilm adheres to several surfaces and causes persistent contamination in various industries including food. ${ }^{[31]}$ To solve this problem, new cleaning and disinfection agents with anti-biofilm activity are required. For this reason, the possible antibacterial and antibiofilm activity of metal complexes and the free ligand was investigated.

Herein, the synthesis, structural, and spectroscopic characterisation of $\mathrm{Cu}^{\mathrm{II}}, \mathrm{Ni}^{\mathrm{II}}, \mathrm{Co}^{\mathrm{II}}$, and $\mathrm{Mn}^{\mathrm{III}}$ complexes with a 1,4-DZP derivative, HDZP $=(6 Z)$-6-(7-trifluoromethyl-1,2,3,4tetrahydro-5H-1,4-diazepin-5-ylidene)cyclohexa-2,4-dien-1-one (Scheme 1) is reported. Recently, this compound was fully characterised and its tautomerism was studied in solid, solution, and gas phase. ${ }^{[32]}$ The synthesised compounds were characterised by FT-IR, UV-vis, and diffuse reflectance spectroscopic studies. The crystal structure of the $\mathrm{Cu}^{\mathrm{II}}$ complex has been solved by X-ray diffraction methods and a detailed analysis of the main intermolecular interactions has been evaluated by Hirshfeld surface (HS) analysis. Thus, the compound surface was mapped by using $d_{\text {norm }}$, shape index, and curvedness properties, for the exploration of the packing modes and visualisation of the intermolecular interactions. The role of non-covalent interactions in the stability of the crystal packing was evaluated by using density functional theory (DFT) calculations and topological analysis of the electron density by Bader's atoms in molecules (AIM) approach.

\section{Experimental}

\section{Synthetic Procedures}

The ligand HDZP was synthesised as previously reported ${ }^{[32,33]}$ by mixing ethanolic solutions of 2-trifluoromethylchromone $(4 \mathrm{mmol})$ and ethylendiamine $(4 \mathrm{mmol})$ at room temperature as shown in Scheme 2. The orange solid thus obtained was recrystallised from hot ethanol.

Anal. Calc. for $\mathrm{C}_{12} \mathrm{H}_{11} \mathrm{~F}_{3} \mathrm{~N}_{2} \mathrm{O}$ : C 56.25, H 4.29, N $10.94 \%$. Found: C 56.40, H 4.32, N 10.75 .

\section{Synthesis of $\left[\mathrm{Cu}(\mathrm{DZP})_{2}\right] \cdot 2 \mathrm{H}_{2} \mathrm{O}$ and $\left[\mathrm{Ni}(\mathrm{DZP})_{2}\right]$ Complexes}

$\left[\mathrm{Cu}(\mathrm{DZP})_{2}\right] \cdot 2 \mathrm{H}_{2} \mathrm{O}$ and $\left[\mathrm{Ni}(\mathrm{DZP})_{2}\right]$ complexes were prepared as follows: $\mathrm{NaOH}(0.08 \mathrm{~g}, 2 \mathrm{mmol})$ was added to a solution of $\operatorname{HDZP}(0.512 \mathrm{~g}, 2 \mathrm{mmol})$ in $5 \mathrm{~mL}$ of methanol. The dispersion was mixed with $\mathrm{CuCl}_{2} \cdot 2 \mathrm{H}_{2} \mathrm{O}(0.170 \mathrm{~g}, 1 \mathrm{mmol})$ or $\mathrm{NiCl}_{2} \cdot 6 \mathrm{H}_{2} \mathrm{O}$ $(0.238 \mathrm{~g}, 1 \mathrm{mmol})$ dissolved in $5 \mathrm{~mL}$ of methanol. The mixtures were refluxed at $60^{\circ} \mathrm{C}$ for $4 \mathrm{~h}$ with continuous stirring 


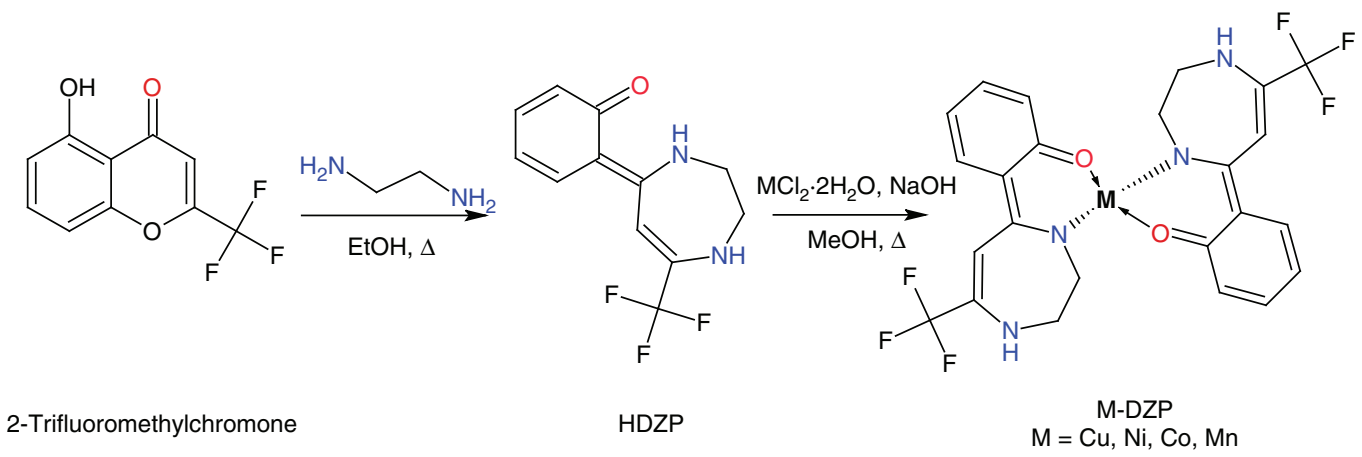

Scheme 2. Synthetic route for the ligand HDZP and its complexes

(see Scheme 2). After cooling, the solids obtained were filtered off, washed with cold methanol, and dried in a desiccator under $\mathrm{CaCl}_{2}$. Only single crystals of $\left[\mathrm{Cu}(\mathrm{DZP})_{2}\right] \cdot 2 \mathrm{H}_{2} \mathrm{O}$ adequate for structural study were obtained from slow evaporation of the solvent (ethanol) at room temperature.

$\left[\mathrm{Cu}(\mathrm{DZP})_{2}\right] \cdot 2 \mathrm{H}_{2} \mathrm{O}$. Yield: $75 \%$. Red crystals. Anal. Calc. for $\mathrm{CuC}_{24} \mathrm{H}_{24} \mathrm{~F}_{6} \mathrm{~N}_{4} \mathrm{O}_{4}$ : C 47.25, H 3.94, N 9.19\%. Found: C 47.32, $\mathrm{H}$ 4.01, N 9.25.

[Ni(DZP $)_{2}$ ]. Yield: $80 \%$. Orange powder. Anal. Calc. for $\mathrm{NiC}_{24} \mathrm{H}_{20} \mathrm{~F}_{6} \mathrm{~N}_{4} \mathrm{O}_{2}$ : C 50.64, H 3.52, N 9.85\%. Found: C 50.15, $\mathrm{H} 3.62$, N 9.83.

\section{Synthesis of $\left[\mathrm{Co}(\mathrm{DZP})_{2}\left(\mathrm{H}_{2} \mathrm{O}\right)_{2}\right] \cdot 2 \mathrm{H}_{2} \mathrm{O}$ and $\left[\mathrm{Mn}(\mathrm{DZP})_{3}\right]$. $2 \mathrm{H}_{2} \mathrm{O}$ Complexes}

The synthetic method for both complexes was similar to $\left[\mathrm{Cu}(\mathrm{DZP})_{2}\right] \cdot 2 \mathrm{H}_{2} \mathrm{O}$ and $\left[\mathrm{Ni}(\mathrm{DZP})_{2}\right]$, except that in these cases $\mathrm{CoCl}_{2} \cdot 6 \mathrm{H}_{2} \mathrm{O}(0.238 \mathrm{~g}, 1 \mathrm{mmol})$ and $\mathrm{MnCl}_{2} \cdot 4 \mathrm{H}_{2} \mathrm{O}(0.198 \mathrm{~g}$, $1 \mathrm{mmol}$ ) were used. The resulting solutions were left to evaporate slowly at room temperature and the obtained powders were dissolved in ethyl acetate and the precipitated $\mathrm{NaCl}$ was separated by filtration. The solvent was evaporated to dryness and the solids were re-crystallised from hot methanol. Due to the amorphous nature of both complexes, single crystals could not be isolated.

$\left[\mathrm{Co}(\mathrm{DZP})_{2}\left(\mathrm{H}_{2} \mathrm{O}\right)_{2}\right] \cdot 2 \mathrm{H}_{2} \mathrm{O}$. Yield: $85 \%$. Green powder. Anal. Calc. for $\mathrm{CoC}_{24} \mathrm{H}_{28} \mathrm{~F}_{6} \mathrm{~N}_{4} \mathrm{O}_{6}$ : C 44.93, H 4.37, N 8.73\%. Found: $\mathrm{C} 44.85, \mathrm{H} 4.30, \mathrm{~N} 8.65$.

$\left[\mathrm{Mn}(\mathrm{DZP})_{3}\right] \cdot 2 \mathrm{H}_{2} \mathrm{O}$. Yield: $82 \%$. Brown powder. Anal. Calc. for $\mathrm{MnC}_{36} \mathrm{H}_{34} \mathrm{~F}_{9} \mathrm{~N}_{6} \mathrm{O}_{5}$ : C 50.47, H 3.97, N 9.81\%. Found: $\mathrm{C}$ 50.72, H 3.98, N 9.77.

\section{Materials and Physical Measurements}

Reagent grade compounds were used for synthesis without further purification. The IR absorption spectra were recorded in the solid state using $\mathrm{KBr}$ pellets on a FTIR Perkin Elmer GX1 in the $4000-400 \mathrm{~cm}^{-1}$ frequency range with $4 \mathrm{~cm}^{-1}$ spectroscopic resolution. Diffuse reflectance UV-Vis spectra of HDZP and its metal complexes were measured using a Shimadzu UV-2600 spectrophotometer equipped with the integrating sphere $\left(\mathrm{BaSO}_{4}\right.$ was used as reference). Elemental analysis of carbon, hydrogen, and nitrogen were performed using a Carlo Erba EA1108 analyser. Thermogravimetric measurements were performed on a Shimadzu TG-50 thermo-balance between 25 and $800^{\circ} \mathrm{C}$ at a heating rate of $5^{\circ} \mathrm{C} \mathrm{min}{ }^{-1}$ under air flow. The magnetic susceptibility measurement for $\left[\mathrm{Mn}(\mathrm{DZP})_{3}\right] \cdot 2 \mathrm{H}_{2} \mathrm{O}$ was performed with a magnetic susceptibility balance (MSB-Auto) at room temperature and diamagnetic corrections were performed using Pascal's constants.

\section{$X$-Ray Diffraction Data and Structure Refinement of $\left[\mathrm{Cu}(\mathrm{DZP})_{2}\right] \cdot 2 \mathrm{H}_{2} \mathrm{O}$}

$\mathrm{X}$-Ray diffraction intensities were collected on an Oxford Xcalibur Gemini, Eos CCD diffractometer employing $\omega$ scans with $\theta$ and $\kappa$-offsets and processed with CrysAlisPro. ${ }^{[34]}$ The unit cell constants were derived from least-squares fitting to the angular setting of all gathered reflections having intensities above seven times the measurement errors. Absorption distortion of diffraction data were corrected employing the empirical multi-scan method. The crystal structure was resolved with the dual method implemented in SHELXT ${ }^{35]}$ and refined with SHELXL. ${ }^{[36]}$ The electron density map showed two types of disorder in the lattice:

(i) Disordered solvent, as confirmed by FT-IR absorption showing the signature of a loosely bonded crystallisation water and by thermogravimetric analysis (TGA) data indicating the loss of two solvent molecules per complex at a relatively low temperature (around $85^{\circ} \mathrm{C}$ ); the solid can thus be described as $\left[\mathrm{Cu}(\mathrm{DZP})_{2}\right] \cdot 2 \mathrm{H}_{2} \mathrm{O}$. This disorder could not be modelled satisfactorily in terms of a discrete solvent distribution and therefore it was resorted to a procedure described by Van der Sluis and Spek ${ }^{[37]}$ and implemented in the program SQUEEZE included in the PLATON suit of programs ${ }^{[38]}$ to remove from the diffraction data the contribution due to this electron density;

(ii) Rotational disorder of the $-\mathrm{CF}_{3}$ group. This was modelled in terms of three angular conformations whose occupancies summed up to one. The $-\mathrm{CF}_{3}$ conformers were refined restraining the $\mathrm{C}-\mathrm{F}$ and $\mathrm{F} \cdots \mathrm{F}$ distances to be respectively equal to one another. The $\mathrm{H}$-atoms were positioned at the expected geometrical locations and refined with the riding model.

Table 1 shows a summary of crystal data and structure refinement results. Crystallographic data have been deposited at the Cambridge Crystallographic Data Centre (CCDC) with the reference number CCDC 1848051.

\section{Hirshfeld Surface Calculations}

HS analysis and the decomposed two-dimensional fingerprint (FP) plots $^{[39-42]}$ were used to understand the nature of intermolecular interactions which stabilise the crystal packing and to quantify the contribution of different contacts. The HS and their associated FP plots were generated using the CrystalExplorer 17 program, ${ }^{[43]}$ using the crystallographic information files (cif) obtained from the X-ray single crystal measurements. The $d_{\text {norm }}$ HS were mapped over a fixed colour scale of -0.025 au (red) to 
Table 1. Crystallographic data and structure refinement results for $\left[\mathrm{Cu}(\mathrm{DZP})_{2}\right] \cdot 2 \mathrm{H}_{2} \mathrm{O}$

\begin{tabular}{|c|c|}
\hline Parameter & {$\left[\mathrm{Cu}(\mathrm{DZP})_{2}\right] \cdot 2 \mathrm{H}_{2} \mathrm{O}$} \\
\hline Empirical formula & $\mathrm{C}_{24} \mathrm{H}_{20} \mathrm{CuF}_{6} \mathrm{~N}_{4} \mathrm{O}_{2}$ \\
\hline Formula weight & 573.98 \\
\hline Temperature $[\mathrm{K}]$ & 294(2) \\
\hline Wavelength [̊] & 0.71073 \\
\hline Crystal system & Monoclinic \\
\hline Space group & $P 2_{1} / c$ \\
\hline$a[\AA]$ & $8.5718(4)$ \\
\hline$b[\AA]$ & $12.6039(5)$ \\
\hline$c[\AA]$ & $12.6422(4)$ \\
\hline$\beta$ [deg.] & $98.803(4)$ \\
\hline Volume $\left[\AA^{3}\right]$ & $1349.75(9)$ \\
\hline $\mathrm{Z}$, density [calc., $\mathrm{mg} \mathrm{m}^{-3}$ ] & $2,1.412$ \\
\hline Absorpt. coeff. $\left[\mathrm{mm}^{-1}\right]$ & 0.877 \\
\hline $\mathrm{F}(000)$ & 582 \\
\hline Crystal size $\left[\mathrm{mm}^{3}\right]$ & $0.296 \times 0.221 \times 0.207$ \\
\hline$\theta$-range for data collect [deg.] & 3.233 to 28.927 \\
\hline Index ranges & $\begin{array}{l}-11 \leq h \leq 10,-15 \leq k \leq 16 \\
\quad-17 \leq l \leq 15\end{array}$ \\
\hline Reflections collected & 6168 \\
\hline Independent reflections & 2930 [R(int) 0.0279] \\
\hline Observed reflections $[I>2 \sigma(I)]$ & 2271 \\
\hline Completeness [\%] & $99.8\left(\right.$ to $\left.\theta=25.242^{\circ}\right)$ \\
\hline Refinement method & Full-matrix least-squares on $F^{2}$ \\
\hline Data / restrains / parameters & $2930 / 72 / 223$ \\
\hline Goodness-of-fit on $F^{2}$ & 1.078 \\
\hline Final $R$ indices $^{\mathrm{A}}[I>2 \sigma(I)]$ & $R_{1} 0.0428, w R_{2} 0.1038$ \\
\hline$R$ indices (all data) & $R_{1} 0.0595, w R_{2} 0.1132$ \\
\hline Larg. diff. peak and hole $\left[\mathrm{e} \AA^{3}\right]$ & 0.266 and -0.290 \\
\hline
\end{tabular}

${ }^{\mathrm{A}} R_{1}=\Sigma|| F_{\mathrm{o}}|-| F_{\mathrm{c}}|| \Sigma\left|F_{\mathrm{o}}\right|, w R_{2}=\left[\Sigma w\left(\left|F_{\mathrm{o}}\right|^{2}-\left|F_{\mathrm{c}}\right|^{2}\right)^{2} / \Sigma w\left(\left|F_{\mathrm{o}}\right|^{2}\right)^{2}\right]^{1 / 2}$.

$0.75 \mathrm{au}$ (blue), shape index mapped in the colour range of $-1.0 \mathrm{au}$ (concave) to $1.0 \mathrm{au}$ (convex) and curvedness in the range of $-4.0 \mathrm{au}$ (flat) to $4.0 \mathrm{au}$ (singular). The 2D FP plots were displayed using the translated $0.6-2.4 \AA$ range including reciprocal contacts.

\section{Computational Details}

DFT calculations for $\left[\mathrm{Cu}(\mathrm{DZP})_{2}\right] \cdot 2 \mathrm{H}_{2} \mathrm{O}$ were performed using the Gaussian 09 ${ }^{[44]}$ program at the B3LYP/cc-pVDZ approximation. In order to obtain the calculated energies involved in the intermolecular interactions that stabilise the crystal packing, the crystallographic coordinates were used instead of those from the optimised structure of the assemblies.

The molecular electrostatic potential (MEP) surface was computed at the same level of theory, using the 0.001 a.u. isosurface. To analyse the bonding nature of the compounds, topological analysis of the electron density was performed using the atoms in molecules (AIM) approach. ${ }^{[45]}$

\section{Biological Assays \\ Growth Test}

A 96-well polystyrene microplate assay (flat base) was performed by determining the absorbance. In each well of the microplate (four repetitions), $5 \mu \mathrm{L}$ of compound solutions (4000 and $400 \mu \mathrm{g} \mathrm{mL}^{-1}$ ) were added. Bacterial suspensions were carried out in Luria-Bertani (LB) and Müller-Hinton (MH) broth from overnight cultures in a MH agar plate of Pseudomonas aeruginosa PAO1 and Staphylococcus aureus ATCC 6538, respectively. The bacterial suspension was adjusted to a final concentration of $10^{7}$ colony forming units (CFU) $\mathrm{mL}^{-1}$ and $195 \mu \mathrm{L}$ of that culture was placed in each microplate well, assaying concentrations of 100 and $10 \mu \mathrm{g} \mathrm{mL}^{-1}$ of the compounds. Solvent control (four repetitions) with $5 \mu \mathrm{L}$ of DMSO and $195 \mu \mathrm{L}$ of the culture were used. The 96-well plates were statically incubated at $37^{\circ} \mathrm{C}$ for $24 \mathrm{~h}$ and growth was detected as turbidity $(560 \mathrm{~nm})$ using a microplate reader (Thermo Fisher Scientific Oy Ratastie 2, FI-01620, Vantaa, Finland).

\section{Biofilm Formation Assay}

A micro-method reported previously ${ }^{[46]}$ was used for the biofilm quantification, with few modifications ${ }^{[47]}$ and the influence of the complexes were evaluated after $24 \mathrm{~h}$ incubation, using crystal violet. The results obtained were processed in Excel and analysed with the statistical program Minitab 1.6. An asterisk was used to indicate significant differences $(P<0.05)$.

\section{Minimal Inhibitory Concentration (MIC) and Minimal Bactericidal Concentration (MBC) Determination}

This test was performed in micro plates. The MIC of the most active compound found in the growth test described in the section Growth Test was determined by the broth micro dilution technique according to the Clinical and Laboratory Standards Institute (CLSI). ${ }^{[48]}$ The concentrations tested were 8, 16, 32, 64, 128, 256,512 , and $1024 \mu \mathrm{g} \mathrm{mL}^{-1}$. The bacterial inoculum $(100 \mu \mathrm{L})$ containing $5 \times 10^{5} \mathrm{CFU} \mathrm{\textrm {mL } ^ { - 1 }}$ was individually added to each well. All controls were performed for sterility, viability, solvent effect (DMSO 2\%), and an antibiotic (ciprofloxacin) used as reference. After incubation at $37^{\circ} \mathrm{C}$ during $24 \mathrm{~h}$, for controls and samples under study, it was determined in which well the formation of a microbial precipitate was not observed. The MIC was the concentration of each sample that inhibits microbial development. From these samples, a $10 \mu \mathrm{L}$ aliquot was extracted and plated in fresh medium for $24 \mathrm{~h}$ at the same temperature to evaluate which samples were able to kill bacteria (MBC).

\section{Results and Discussion}

\section{Synthesis of Metal Complexes}

The synthesis of the complexes was performed by mixing methanolic solutions of $\mathrm{CuCl}_{2} \cdot 2 \mathrm{H}_{2} \mathrm{O}, \mathrm{NiCl}_{2} \cdot 6 \mathrm{H}_{2} \mathrm{O}, \mathrm{CoCl}_{2} \cdot 6 \mathrm{H}_{2} \mathrm{O}$, and $\mathrm{MnCl}_{2} \cdot 4 \mathrm{H}_{2} \mathrm{O}$ for $\left[\mathrm{Cu}(\mathrm{DZP})_{2}\right] \cdot 2 \mathrm{H}_{2} \mathrm{O},\left[\mathrm{Ni}(\mathrm{DZP})_{2}\right]$, [Co$\left.(\mathrm{DZP})_{2}\left(\mathrm{H}_{2} \mathrm{O}\right)_{2}\right] \cdot 2 \mathrm{H}_{2} \mathrm{O}$, and $\left[\mathrm{Mn}(\mathrm{DZP})_{3}\right] \cdot 2 \mathrm{H}_{2} \mathrm{O}$, respectively and the corresponding HDZP ligand (see Scheme 2). The ligand-tometal molar ratio was $2: 1$ for all complexes. The resulting products were coloured powders and the crystal structure of $\left[\mathrm{Cu}(\mathrm{DZP})_{2}\right] \cdot 2 \mathrm{H}_{2} \mathrm{O}$ was solved by single crystal X-ray diffraction measurements. Elemental analysis and TGA data were satisfactory with the proposed empirical formula. These results also revealed that the initial ligand-to-metal ratio of 2.1 was maintained for $\mathrm{Cu}^{\mathrm{II}}, \mathrm{Ni}^{\mathrm{II}}$, and $\mathrm{Co}{ }^{\mathrm{II}}$ complexes, but the ratio of $3: 1$ was observed for the $\mathrm{Mn}^{\mathrm{III}}$ complex. In $\left[\mathrm{Mn}(\mathrm{DZP})_{3}\right] \cdot 2 \mathrm{H}_{2} \mathrm{O}, \mathrm{Mn}^{\mathrm{II}}$ was oxidised by atmospheric oxygen to $\mathrm{Mn}^{\mathrm{III}}$ under the reaction conditions. ${ }^{[49]}$ The value of the magnetic moment at room temperature $\left(3.00 \mu_{\mathrm{B}}\right)$ is close to the spin-only value of $2.88 \mu_{\mathrm{B}}$, as expected for a low-spin $\mathrm{d}^{4}$ manganese(III) ion.

\section{Spectroscopic Studies \\ FT-IR Spectroscopy}

The FT-IR spectra of the complexes were compared with free HDZP, as shown in Fig. 1. The HDZP spectrum has numerous bands and the most relevant ones related to the coordination sites 


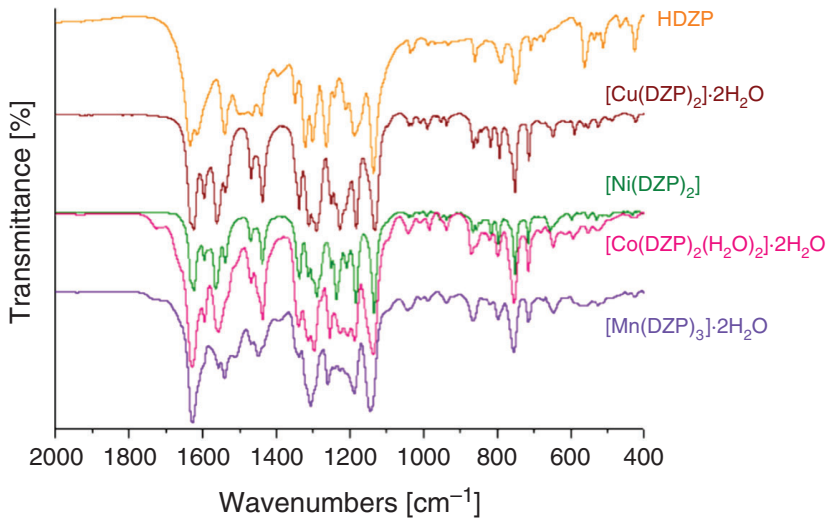

Fig. 1. FT-IR spectra of HDZP ligand and its $\mathrm{Cu}^{\mathrm{II}}, \mathrm{Ni}^{\mathrm{II}}, \mathrm{Co}^{\mathrm{II}}$, and $\mathrm{Mn}^{\mathrm{III}}$ complexes.

could be assigned (See Table S1, Supplementary Material). The HDZP ligand could exist in three tautomeric forms, as shown in Scheme 1. The crystal structure of the HDZP ligand indicates that the most stable form in the solid state is the keto-enamine tautomer. This is in accordance with the intense absorption band observed at $1635 \mathrm{~cm}^{-1}$ in the IR spectrum of the solid, assigned to the $\mathrm{C}=\mathrm{O}$ stretching mode. Several bands between 3080 and $2865 \mathrm{~cm}^{-1}$ in the free ligand and its metal complexes are attributed to $\mathrm{C}-\mathrm{H}$ stretching vibrations of aromatic and aliphatic hydrogens. The bands corresponding to the $v(\mathrm{O}-\mathrm{H})$ modes of non-coordinated water molecules in $\left[\mathrm{Cu}(\mathrm{DZP})_{2}\right] \cdot 2 \mathrm{H}_{2} \mathrm{O}$ are not clearly visible in the IR spectrum because they are overlapped with the bands related to the $\mathrm{N}-\mathrm{H}$ stretching mode (see Fig. S1, Supplementary Material). The spectra of $\left[\mathrm{Co}(\mathrm{DZP})_{2}\left(\mathrm{H}_{2} \mathrm{O}\right)_{2}\right]$. $2 \mathrm{H}_{2} \mathrm{O}$ and $\left[\mathrm{Mn}(\mathrm{DZP})_{3}\right] \cdot 2 \mathrm{H}_{2} \mathrm{O}$ show a broad band in the 3550 $3375 \mathrm{~cm}^{-1}$ frequency range, according to the existence of water molecules in the complexes (see Figs S3 and S4, Supplementary Material). The other corresponding bands of water molecules could not be assigned, due to the fact that they overlapped with some other modes. The frequency of the N1-H stretching of the diazepine, observed at $2768 \mathrm{~cm}^{-1}$ in the free ligand, was not detected in the spectra of the complexes, confirming the deprotonation of the $\mathrm{N} 1-\mathrm{H}$ moiety. The $\mathrm{C} 7-\mathrm{N} 1$ stretching vibration located at around $1540 \mathrm{~cm}^{-1}$ in HDZP is shifted towards higher frequencies upon complexation with metal ions. The $\mathrm{C}=\mathrm{O}$ stretching mode of the keto-enamine tautomer of HDZP in the solid state appears as an intense band at $1635 \mathrm{~cm}^{-1}$ whereas, for all complexes, the $\mathrm{C}=\mathrm{O}$ stretching vibration is shifted to lower frequencies (between $1624-1628 \mathrm{~cm}^{-1}$ ) because of the increased length of the $\mathrm{C}=\mathrm{O}$ bond coordinated to the metal ions. The band at $1615 \mathrm{~cm}^{-1}$ associated with $\mathrm{C}-\mathrm{C}$ stretching modes of the phenyl ring changed slightly upon complexation, indicating that the complex formation alters the ring structure. The bands corresponding to the vibrations of the diazepine ring were, in some extent, affected by the interaction of HDZP with the metal ions (see Table $\mathrm{S} 1$ ). The evident negative shift of the $\mathrm{C}-\mathrm{C}=\mathrm{O}$ bending mode in the complexes suggests that the ligand coordinates the metal ions by the oxygen atoms, which is confirmed by the crystal structure determination of $\left[\mathrm{Cu}(\mathrm{DZP})_{2}\right] \cdot 2 \mathrm{H}_{2} \mathrm{O}$ (see below). The metal complexes exhibit bands in the range 552 $593 \mathrm{~cm}^{-1}$ and $451-488 \mathrm{~cm}^{-1}$ which are assigned to $\mathrm{M}-\mathrm{N}$ and $\mathrm{M}-\mathrm{O}$ stretching modes, indicating that the coordination of the metal ions with the HDZP ligand took place probably via carbonyl oxygen and N1 atoms of the DZP ring after deprotonation.

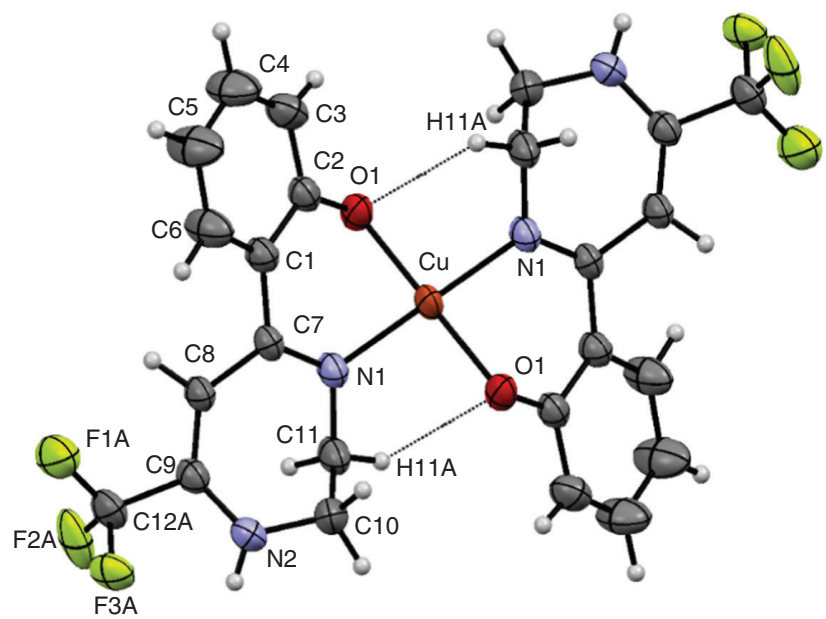

Fig. 2. Plot of the molecular structure of $\left[\mathrm{Cu}(\mathrm{DZP})_{2}\right]$, showing the atomic labelling and the displacement ellipsoids of non- $\mathrm{H}$ atoms at the $50 \%$ probability level. Intramolecular hydrogen bonds are shown as dashed lines. For clarity, from the three rotationally split positions that model the rotational disorder of the $-\mathrm{CF}_{3}$ group, only the conformation having the largest occupancy is shown.

\section{Electronic Spectroscopy}

The electronic absorption spectra of the ligand and its metal complexes (Fig. S5, Supplementary Material) were recorded in the solid state at room temperature. The electronic data of the HDZP ligand and the $\left[\mathrm{Cu}(\mathrm{DZP})_{2}\right] \cdot 2 \mathrm{H}_{2} \mathrm{O},\left[\mathrm{Ni}(\mathrm{DZP})_{2}\right]$, [Co$\left.(\mathrm{DZP})_{2}\left(\mathrm{H}_{2} \mathrm{O}\right)_{2}\right] \cdot 2 \mathrm{H}_{2} \mathrm{O}$, and $\left[\mathrm{Mn}(\mathrm{DZP})_{3}\right] \cdot 2 \mathrm{H}_{2} \mathrm{O}$ complexes are summarised in Table S2 (Supplementary Material). The ligand shows absorptions bands at 254 and $279 \mathrm{~nm}$ attributed to $\pi \rightarrow \pi^{*}$ transitions and a band at $352 \mathrm{~nm}$ which could be assigned to $\mathrm{n} \rightarrow \pi^{*}$ transitions. The electronic spectra of $\left[\mathrm{Cu}(\mathrm{DZP})_{2}\right] \cdot 2 \mathrm{H}_{2} \mathrm{O}$ and $\left[\mathrm{Ni}(\mathrm{DZP})_{2}\right]$ exhibit three bands at 231,290 , and $337 \mathrm{~nm}$ and at 234,268 , and $334 \mathrm{~nm}$, respectively. These absorptions correspond to intra-ligand transitions. The absorption bands at 492 and $674 \mathrm{~nm}$ in the electronic spectra of $\left[\mathrm{Cu}(\mathrm{DZP})_{2}\right] \cdot 2 \mathrm{H}_{2} \mathrm{O}$ are assigned to ${ }^{2} \mathrm{~B}_{1 \mathrm{~g}} \rightarrow{ }^{2} \mathrm{~B}_{2 \mathrm{~g}}$ and ${ }^{2} \mathrm{~B}_{1 \mathrm{~g}} \rightarrow{ }^{2} \mathrm{~A}_{1 \mathrm{~g}}$ transitions, respectively. The broad band at $563 \mathrm{~nm}$ in the $\left[\mathrm{Ni}(\mathrm{DZP})_{2}\right]$ spectra is attributed to the ${ }^{1} \mathrm{~A}_{1 \mathrm{~g}} \rightarrow{ }^{1} \mathrm{~B}_{1 \mathrm{~g}}$ electronic transition. These results are consistent with the square-planar geometry of $\mathrm{Cu}^{\mathrm{II}}$ and $\mathrm{Ni}^{\mathrm{II}}$ in the complexes. ${ }^{[50]}$ The $\left[\mathrm{Cu}(\mathrm{DZP})_{2}\right] \cdot 2 \mathrm{H}_{2} \mathrm{O}$ and $\left[\mathrm{Ni}(\mathrm{DZP})_{2}\right]$ spectra exhibit absorption bands at 387 and $389 \mathrm{~nm}$, respectively which can be attributed to ligand to metal charge transfer (LMCT) transitions. The $\left[\mathrm{Co}(\mathrm{DZP})_{2}\left(\mathrm{H}_{2} \mathrm{O}\right)_{2}\right] \cdot 2 \mathrm{H}_{2} \mathrm{O}$ spectrum shows bands at 418 and $629 \mathrm{~nm}$ attributed to ${ }^{4} \mathrm{~T}_{1 \mathrm{~g}}(\mathrm{~F}) \rightarrow{ }^{4} \mathrm{~T}_{1 \mathrm{~g}}(\mathrm{P})$ and ${ }^{4} \mathrm{~T}_{1 \mathrm{~g}}(\mathrm{~F}) \rightarrow{ }^{4} \mathrm{~A}_{2 \mathrm{~g}}(\mathrm{~F})$ transitions, respectively. These bands are in accordance with an octahedral geometry of the $\mathrm{Co}^{\mathrm{II}}$ ion. $^{[51]}$ The electronic spectrum of the $\left[\mathrm{Mn}(\mathrm{DZP})_{3}\right] \cdot 2 \mathrm{H}_{2} \mathrm{O}$ complex exhibits an absorption at $408 \mathrm{~nm}$ attributed to LMCT, typically of $\mathrm{Mn}^{\text {III }}$ complexes. ${ }^{[52]}$

\section{Description of Crystal and Molecular Structure of $\left[\mathrm{Cu}(\mathrm{DZP})_{2}\right] \cdot 2 \mathrm{H}_{2} \mathrm{O}$}

Fig. 2 shows an $O R T E P^{[53]}$ drawing of the $\left[\mathrm{Cu}(\mathrm{DZP})_{2}\right]$ complex and selected bond lengths and angles are listed in Table 2. The experimental geometrical parameters are compared in Table S3 (Supplementary Material) with the corresponding calculated ones at the B3LYP/cc-pVDZ level of theory. The metal is sited on a crystallographic inversion centre, in a square planar environment, coordinated to two deprotonated DZP anions, acting as bidentate ligands through its carbonyl oxygen 
$(d(\mathrm{Cu}-\mathrm{O})=1.925(2) \AA)$ and amine nitrogen $(d(\mathrm{Cu}-\mathrm{N})=$ $1.979(2) \AA)$ atoms nearly along their electron lone-pair lobes maximising their overlap with the copper $\mathrm{d}\left(x^{2}-y^{2}\right)$ orbital.

The bond lengths and angles are like those observed in related complexes. ${ }^{[54-56]}$ In a previous work, the crystal structure of the free HDZP ligand was fully elucidated by DRX, resulting in the keto-enamine being the preferred tautomer in the solid state $(\mathrm{O}=\mathrm{C}(\mathrm{R})-\mathrm{C}=\mathrm{C}-\mathrm{N}-\mathrm{H}(\mathrm{R})) .{ }^{[33]}$ Most bond lengths of the DZP ligand in the copper complex are remarkably similar to the corresponding ones of the HDZP ligand. Upon its coordination to the $\mathrm{Cu}^{\mathrm{II}}$ ion, the most significant changes are the lengthening of the carbonyl $\mathrm{C}=\mathrm{O}$ bond (in $+0.016 \AA$ or $\sim 5 \sigma$ ) and to a lesser extent to a shortening of the amino $\mathrm{C}-\mathrm{N}$ bond (in $-0.01 \AA=-2.8 \sigma$ ). In addition, a lengthening of the bond connecting the aromatic and the DZP rings (C1-C7: 1.475(4) $\AA$ ) and a shortening of the $\mathrm{C} 1-\mathrm{C} 2$ bond (1.421(4) $\AA$, aromatic ring) with respect to the free ligand (1.459 and $1.304 \AA$, respectively) is observed. This can be understood assuming that the interatomic distance changes observed between the free and the coordinate HDZP ligand corresponds to a charge distribution oriented to the resonance form $\left({ }^{-} \mathrm{O}-\mathrm{C}(\mathrm{R})=\mathrm{C}-\mathrm{C}=\mathrm{N}(\mathrm{R})\right)$. Since the ligand is deprotonated before the complex formation, the interatomic distances reflect the weight of each resonance forms

Table 2. Experimental and calculated bond lengths and angles for $\left[\mathrm{Cu}(\mathrm{DZP})_{2}\right]$

\begin{tabular}{lcc}
\hline Bonds & Experimental $^{\mathrm{A}}$ & Calculated $^{\mathrm{B}}$ \\
\hline & & Lengths [A] \\
$\mathrm{Cu}-\mathrm{N}$ & $1.979(2)$ & 2.011 \\
$\mathrm{Cu}-\mathrm{O}$ & $1.925(2)$ & 1.927 \\
$\mathrm{~N} 1-\mathrm{C} 7$ & $1.305(3)$ & 1.319 \\
$\mathrm{~N} 1-\mathrm{C} 11$ & $1.458(4)$ & 1.459 \\
$\mathrm{C} 11-\mathrm{C} 10$ & $1.533(4)$ & 1.537 \\
$\mathrm{C} 10-\mathrm{N} 2$ & $1.442(4)$ & 1.455 \\
$\mathrm{~N} 2-\mathrm{C} 9$ & $1.334(3)$ & 1.355 \\
$\mathrm{C} 9-\mathrm{C} 12 \mathrm{~A}$ & $1.519(4)$ & 1.523 \\
$\mathrm{C} 9-\mathrm{C} 8$ & $1.354(4)$ & 1.369 \\
$\mathrm{C} 8-\mathrm{C} 7$ & $1.456(3)$ & 1.464 \\
$\mathrm{C} 7-\mathrm{C} 1$ & $1.475(4)$ & 1.473 \\
$\mathrm{C} 2-\mathrm{O}$ & $1.320(3)$ & 1.309 \\
$\mathrm{C} 2-\mathrm{C} 1$ & $1.421(3)$ & 1.438 \\
$\mathrm{C} 2-\mathrm{C} 3$ & $1.401(4)$ & 1.425 \\
& & \\
O\#1-Cu-N1 & Angles [deg.] & 91.22 \\
$\mathrm{O} \# 1-\mathrm{Cu}-\mathrm{O}$ & $92.37(9)$ & 179.9 \\
$\mathrm{~N} 1-\mathrm{Cu}-\mathrm{N} \# 1$ & 180.0 & 179.9 \\
$\mathrm{C} 7-\mathrm{N} 1-\mathrm{Cu}$ & 180.0 & 123.4 \\
$\mathrm{C} 11-\mathrm{N} 1-\mathrm{Cu}$ & $123.94(18)$ & 115.8 \\
$\mathrm{C} 2-\mathrm{O}-\mathrm{Cu}$ & $117.38(17)$ & 123.4 \\
\hline
\end{tabular}

${ }^{\mathrm{A}}$ Experimental parameters obtained in this work.

${ }^{\mathrm{B}}$ Calculated at B3LYP/cc-pVDZ level. depicted in Scheme 3. Considering the observed results, it can be concluded that II is the predominant form.

The $\left[\mathrm{Cu}(\mathrm{DZP})_{2}\right]$ crystal structure is further stabilised by an extensive network of intermolecular $\mathrm{N}-\mathrm{H} \cdots \mathrm{O}$ hydrogen bonds between neighbouring complexes $\left(d\left(\mathrm{~N} 2 \cdots \mathrm{O}^{\prime}\right)=2.871(3) \AA\right.$, $\left.d\left(\mathrm{H} \cdots \mathrm{O}^{\prime}\right)=2.17 \AA,<\left(\mathrm{N} 2-\mathrm{H} \cdots \mathrm{O}^{\prime}\right)=139^{\circ}\right)$, giving rise to a layered structure parallel to the crystal (100) plane (see Fig. 3). More details of the hydrogen bonding interactions are listed in Table S3.

The weak non-covalent interactions such as $\mathrm{C}-\mathrm{H} \cdots \mathrm{X}$ ( $\mathrm{X}=\mathrm{N}, \mathrm{O}, \mathrm{S}$, or halogen) and $\pi$-stacking are weaker than classical hydrogen bonds and they have an important role in structural biology and supramolecular chemistry. ${ }^{[57,58]}$ In addition, these interactions also have the ability to regulate antigenantibody recognition. ${ }^{[59]}$ In the crystal structure of $\left[\mathrm{Cu}(\mathrm{DZP})_{2}\right]$, two identical intramolecular $\mathrm{C}-\mathrm{H} \cdots \mathrm{O}$ contacts are observed (see Fig. 2). Intramolecular hydrogen bonds occur between C11-H11A … O (2.47(3) $\AA$ ) atoms with the formation of fivemembered rings $(\mathrm{Cu}-\mathrm{N} 1-\mathrm{C} 11-\mathrm{H} 11 \mathrm{~A}-\mathrm{O})$. The crystal structure of $\left[\mathrm{Cu}(\mathrm{DZP})_{2}\right]$ shows chelate ring $(\mathrm{CR}) \cdots \mathrm{H}$ interactions, with a $\mathrm{Cg} 1 \cdots \mathrm{H}$ distance of $3.047 \AA(\mathrm{Cg} 1=\mathrm{Cu} / \mathrm{O} / \mathrm{C} 2 / \mathrm{C} 1 / \mathrm{C} 7 / \mathrm{N} 1)$, as shown in Fig. 4. Recently, numerous investigations reported evidence of $\mathrm{C}-\mathrm{H} \cdots \pi$ and $\pi$-stacking interactions with the $\pi$-cloud of a six-membered chelate ring due to the planarity and delocalisation of the $\pi$-system. ${ }^{[27-29]}$ Also, there are intermolecular $\mathrm{C}-\mathrm{H} \cdots \pi$ interactions $(\mathrm{C} 11-\mathrm{H} 11 \mathrm{~A} \cdots \mathrm{Cg} 2=3.875 \AA$ ), where $\mathrm{Cg} 2$ is the ring centroid defined by atoms $\mathrm{C} 1-\mathrm{C} 6$ (see Fig. S6, Supplementary Material). The nature of the CR $\cdots H$ interaction is discussed in the theoretical study (section Theoretical Results).

\section{Hirshfeld Surface Analysis}

HS analysis is an important tool in the study of crystal structures of numerous inorganic and organic compounds, since this method proposes a facile way of obtaining information about intermolecular interactions that stabilise the crystal packing. ${ }^{[41]}$

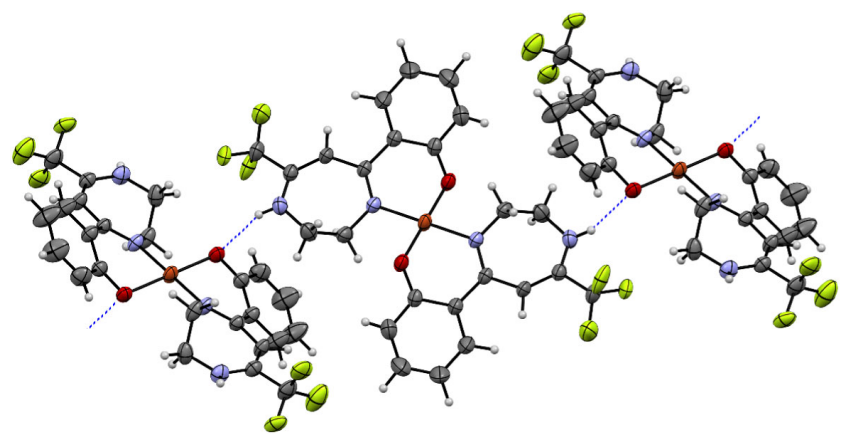

Fig. 3. Partial view of the crystal structure of $\left[\mathrm{Cu}(\mathrm{DZP})_{2}\right]$ showing $\mathrm{N}-\mathrm{H} \cdots \mathrm{O}$ intermolecular hydrogen bonds as dashed lines.
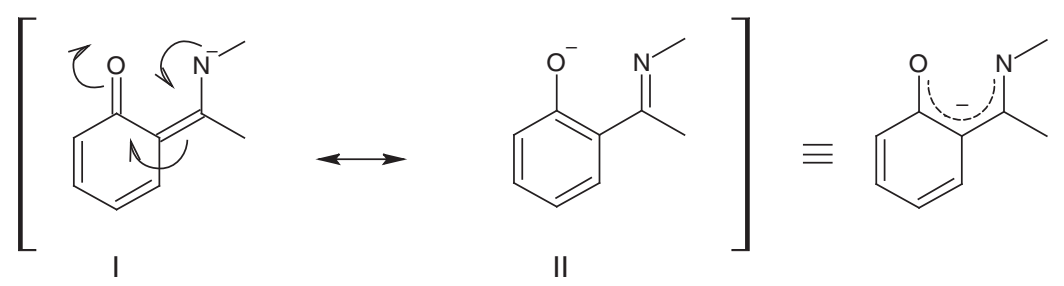

Scheme 3. Resonance forms of the HDZP ligand. 
The HSs mapped over $d_{\text {norm }}$ properties are displayed in Fig. 5a. The HSs, mapped over shape index and curvedness, are shown in Figs S6 and S7 (Supplementary Material). The deep red visible spots on the HS is indicative of $\mathrm{O} \cdots \mathrm{H}$ and $\mathrm{F} \cdots \mathrm{H}$ contacts. The dominant interactions are observed in $d_{\text {norm }}$ surface plots as bright areas in Fig. 5a. The full 2D FP plot of $[\mathrm{Cu}-$ $(\mathrm{DZP})_{2}$ ] illustrates the significant differences between the intermolecular interaction patterns. In the FP plot (Fig. 5b), O $\cdots$ $\mathrm{H}, \mathrm{F} \cdots \mathrm{H}$, and $\mathrm{C} \cdots \mathrm{H}$ interactions are represented by spikes in the bottom right area, in the same way, the $\mathrm{H} \cdots \mathrm{O}, \mathrm{H} \cdots \mathrm{F}$, and $\mathrm{H} \cdots \mathrm{C}$ contacts are visualised in the top left region.

According to the HS analysis, the non-directional $\mathrm{H} \cdots \mathrm{H}$ contacts, comprising $25.3 \%$ of the total HS, are one of major contributors to the crystal packing. As shown in Fig. 5, the shortest $\mathrm{H} \cdots \mathrm{H}$ contacts in the FP plot are at $\left(\mathrm{d}_{\mathrm{e}}+\mathrm{d}_{\mathrm{i}}\right) 2.45 \AA$. The $\mathrm{H} \cdots \mathrm{H}$ contacts are generally characterised by broader or sharper spikes in the FP plots. Furthermore, a subtle feature, the splitting of the $\mathrm{H} \cdots \mathrm{H}$ contact in the FP plot is evident for $\left[\mathrm{Cu}(\mathrm{DZP})_{2}\right]$. This splitting occurs when the shorter contact is between three atoms, rather than a direct two-atom contact.

The proportions of $\mathrm{H} \cdots \mathrm{O} / \mathrm{O} \cdots \mathrm{H}$ interactions comprise $6.3 \%$ of the total HS and are characterised by spikes at $d_{e}+d_{i}$

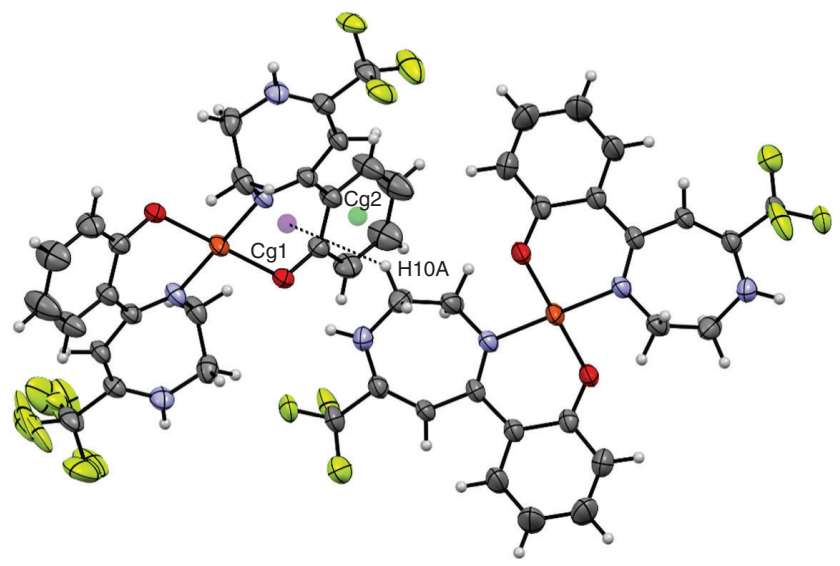

Fig. 4. Crystal packing of $\left[\mathrm{Cu}(\mathrm{DZP})_{2}\right]$ showing $\mathrm{C}-\mathrm{H} \cdots \pi(\mathrm{CR})$ contacts $\mathrm{Cg} 1$ and $\mathrm{Cg} 2$ are centroids defined by $\mathrm{Cu} / \mathrm{O} / \mathrm{C} 2 / \mathrm{C} 1 / \mathrm{C} 7 / \mathrm{N} 1$ and $\mathrm{C} 1-\mathrm{C} 6$ atoms, respectively. $\sim 1.95 \AA$, associated to $\mathrm{N} 1-\mathrm{H} \cdots \mathrm{O} 1$ intermolecular interactions. These interactions seem to be relevant, as indicated by the deep red spots in the $d_{\text {norm }}$ map labelled 1 .

The most important contacts are $\mathrm{H} \cdots \mathrm{F} / \mathrm{F} \cdots \mathrm{H}$, with a magnitude of $39.9 \%$ of the total HS area. The red spots labelled as 2 and 4 on the $d_{\text {norm }}$ surface are associated to C4-H4 $\cdots$ F1A and C6-H6 ‥F1A interactions, respectively (see Fig. S9, Supplementary Material) with $\mathrm{H} \cdots \mathrm{F} 1 \mathrm{~A}$ distances of 2.590 and $2.658 \AA$. The red spots labelled 3 in the $d_{\text {norm }}$ map are associated to $\mathrm{C}-\mathrm{H} \cdots \mathrm{F}$ intermolecular interactions. The $\mathrm{F} 3 \mathrm{~A}$ atom is involved with the $\mathrm{H} 10 \mathrm{~B}$ of the methylene group embedded in the DZP ring through a non-classical intermolecular hydrogen bond $\mathrm{C} 10-\mathrm{H} 10 \mathrm{~B} \cdots \mathrm{F} 3 \mathrm{~A}$, with a H $\cdots$ A distance of $2.660 \AA$ (see Fig. S10, Supplementary Material).

The FP plots also show $\mathrm{C} \cdots \mathrm{H} / \mathrm{H} \cdots \mathrm{C}$ intermolecular interactions that involve $14.2 \%$ of the total HS.

The shape index and curvedness maps (Figs S7 and S8) are significant indicators for $\pi$-stacking interactions within the crystal structure. For $\left[\mathrm{Cu}(\mathrm{DZP})_{2}\right]$, no complementary red and blue triangles have been observed in the shape index map indicating the absence of $\pi \cdots \pi$ interactions.

\section{Thermal Analysis}

TGA was applied to investigate the thermal stability and behaviour of $\left[\mathrm{Cu}(\mathrm{DZP})_{2}\right] \cdot 2 \mathrm{H}_{2} \mathrm{O}, \quad\left[\mathrm{Ni}(\mathrm{DZP})_{2}\right], \quad\left[\mathrm{Co}(\mathrm{DZP})_{2}-\right.$ $\left.\left(\mathrm{H}_{2} \mathrm{O}\right)_{2}\right] \cdot 2 \mathrm{H}_{2} \mathrm{O}$, and $\left[\mathrm{Mn}(\mathrm{DZP})_{3}\right] \cdot 2 \mathrm{H}_{2} \mathrm{O}$ complexes. The results are shown in Figs S11-S14 (Supplementary Material).

The $\left[\mathrm{Cu}(\mathrm{DZP})_{2}\right] \cdot 2 \mathrm{H}_{2} \mathrm{O}$ complex decomposes in a three-stage process. The first mass loss step is observed at $\sim 85^{\circ} \mathrm{C}$ and corresponds to the removal of two water molecules (exp. mass loss: $6.54 \%$, theoretical: $6.00 \%$ ). The dehydration process was observed at low temperature because the water molecules are weakly bonded (uncoordinated water molecules). The second and third mass losses are associated to the degradation of DZP ligands to form $\mathrm{CuO}$ as a final product. The observed mass loss $(87.0 \%)$ is in very good agreement with the calculated value $(87.5 \%)$.

The curve for the thermal decomposition of $\left[\mathrm{Ni}(\mathrm{DZP})_{2}\right]$ exhibits two pronounced mass loss steps. It starts at temperatures above $300^{\circ} \mathrm{C}$ and the two consecutive steps are associated with the removal of two DZP molecules to form $\mathrm{NiO}$ as the final product (exp. mass loss: $88.0 \%$, theoretical mass loss: $87.0 \%$ ). (a)

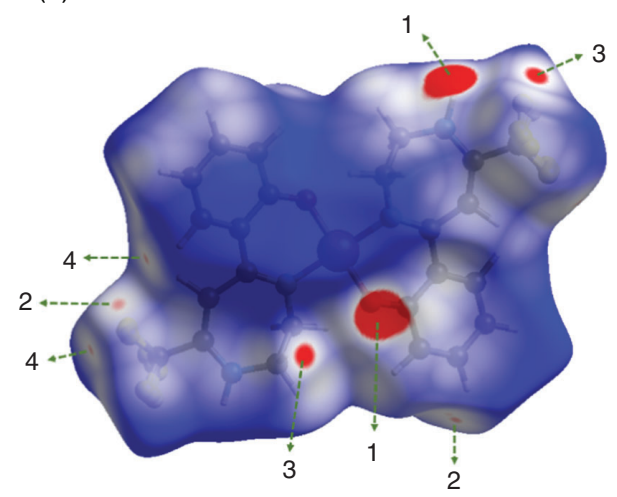

(b)

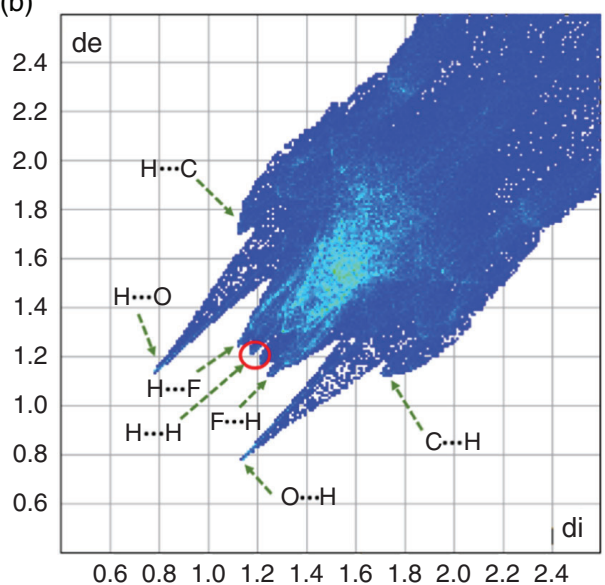

Fig. 5. (a) Hirshfeld surface mapped over $d_{\text {norm }}$ and (b) full $2 \mathrm{D}$ fingerprint plot of the $\left[\mathrm{Cu}(\mathrm{DZP})_{2}\right]$ complex showing the spikes of the main intermolecular contacts in the crystal packing. 
The first step for the thermal decomposition of $\left[\mathrm{Co}(\mathrm{DZP})_{2}-\right.$ $\left.\left(\mathrm{H}_{2} \mathrm{O}\right)_{2}\right] \cdot 2 \mathrm{H}_{2} \mathrm{O}$ finishes at $\sim 130^{\circ} \mathrm{C}$ with an experimental mass loss of $5.54 \%$ (theoretical value: $5.62 \%$ ), and can be attributed to the loss of two non-coordinated water molecules. The second decomposition process finishes at $200^{\circ} \mathrm{C}$ and corresponds to the removal of two coordinated water molecules with a mass loss of $5.66 \%$ (calculated: $5.58 \%$ ). The next degradation steps occur within the range of $200-450^{\circ} \mathrm{C}$ and are attributed to the removal of two DZP ligands to form $\mathrm{CoO}$ as the final product. The experimental mass loss $(89.1 \%)$ agrees with that calculated $(88.3 \%)$ for the complete exclusion of all DZP ligands. In accordance with elemental analysis and thermal data we can conclude that the $\mathrm{Co}^{\mathrm{II}}$ ion is in an octahedral environment coordinated to two DZP ligands and two water molecules. A proposed molecular structure for $\left[\mathrm{Co}(\mathrm{DZP})_{2}\left(\mathrm{H}_{2} \mathrm{O}\right)_{2}\right] \cdot 2 \mathrm{H}_{2} \mathrm{O}$ is shown in Fig. S15 (Supplementary Material).

The thermal decomposition of $\left[\mathrm{Mn}(\mathrm{DZP})_{3}\right] \cdot 2 \mathrm{H}_{2} \mathrm{O}$ is quite different. The first step finishes at $150^{\circ} \mathrm{C}$ and it is due to the loss of two weakly bonded water molecules (exp. mass loss: $4.26 \%$, theoretical: $4.20 \%$ ). The subsequent decomposition processes are associated with the combustion of the three DZP ligands, with a total mass loss of $93.0 \%$, in accordance with the calculated value $(92.0 \%)$ expected for the formation of $\mathrm{Mn}_{3} \mathrm{O}_{4}$ as the final product. These results indicate that the $\mathrm{Mn}^{\mathrm{III}}$ is octahedrally coordinated to three DZP ligands and crystallised with two non-coordinated water molecules (see Fig. S15).

\section{Theoretical Results}

The theoretical study was performed to compare the energetic features of the different types of intermolecular interactions

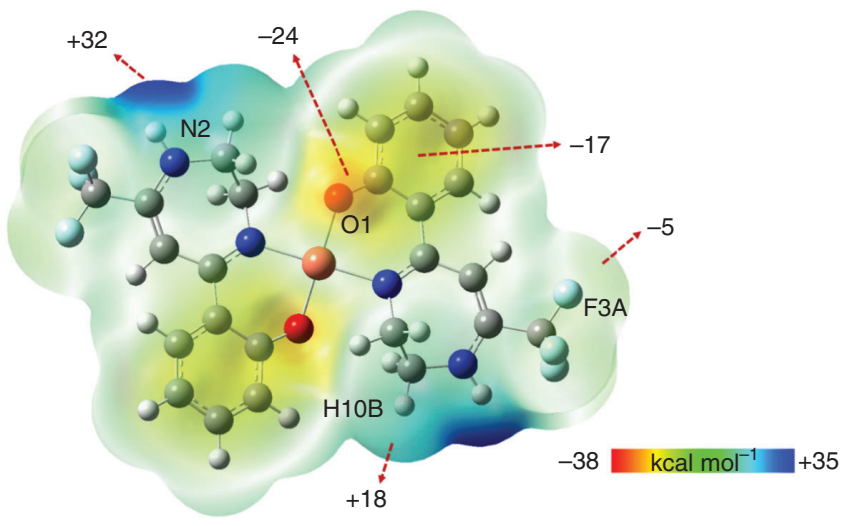

Fig. 6. MEP map of $\left[\mathrm{Cu}(\mathrm{DZP})_{2}\right]$ showing the energetic values at selected points in $\mathrm{kcal} / \mathrm{mol}$. observed in the crystal packing of the $\left[\mathrm{Cu}(\mathrm{DZP})_{2}\right]$ complex. In particular, $\mathrm{N}-\mathrm{H} \cdots \mathrm{O}, \mathrm{C}-\mathrm{H} \cdots \mathrm{F}$, and $\mathrm{C}-\mathrm{H} \cdots \pi$ interactions have been analysed, since they are decisive to understand the crystal packing of the complex. We have computed the molecular electrostatic potential (MEP) to understand the electronic nature of the different donor-acceptor sites and the aromatic and chelate rings (Fig. 6). As shown in Fig. 6, the most negative electrostatic potential corresponds to the region of the $\mathrm{O}$ atoms from the $\mathrm{C}=\mathrm{O}$ group $\left(-24 \mathrm{kcal} \mathrm{mol}^{-1}\right)$ and the most positive part is located in the region of the $\mathrm{N} 2-\mathrm{H}$ bond of the diazepine ring $\left(+32 \mathrm{kcal} \mathrm{mol}^{-1}\right)$. These results are indicative that the hydrogen bonds between these groups should be energetically favoured. In addition, the MEP values are negative over the phenyl rings $\left(-17 \mathrm{kcal} \mathrm{mol}^{-1}\right)$ indicating that the $\mathrm{C}-\mathrm{H} \cdots \pi$ interactions should be preferred. The MEP value at $\mathrm{H} 10 \mathrm{~B}\left(+18 \mathrm{kcal} \mathrm{mol}^{-1}\right)$ is less positive than the $\mathrm{H}$ bonded to $\mathrm{N} 2$, indicating that the $\mathrm{C} 10$ $\mathrm{H} 10 \mathrm{~B} \cdots \mathrm{F} 3 \mathrm{~A}$ interactions are less favoured in the crystal structure.

The dimer shown in Fig. 4 was optimised and the interaction energies were also computed. Moreover, the distribution of bond critical points (BCPs) and bond paths by using the AIM approach were also obtained. A bond path combined with a BCP connecting two atoms is a clear indication of an interaction. ${ }^{[4]}$ In accordance with the crystal structure of $\left[\mathrm{Cu}(\mathrm{DZP})_{2}\right] \cdot 2 \mathrm{H}_{2} \mathrm{O}$, the strongest interactions $\mathrm{N} 2-\mathrm{H} \cdots \mathrm{O} 1$ are responsible for the crystal packing of molecules. AIM analysis shows a complex set of molecular interactions that are outlined in Table 3 and the molecular graphs showing the intermolecular interactions are shown in Fig. S16 (Supplementary Material). The results indicate that the values of electron density and the Laplacian of electron density at the $\mathrm{BCP}$ for all intermolecular contacts (criteria range: $0.002-0.035$ a.u. and $0.024-0.139$ a.u. for $\rho$ and $\nabla^{2}(\rho)$, respectively) confirm the existence of every intermolecular interaction shown in Fig. S16 (Supplementary Material). The energies of the intermolecular interactions at the $\mathrm{BCP}$ have been calculated according to the formula proposed by Espinosa et al.: $E(\mathrm{H} \cdots \mathrm{A})=0.5 V$, where $V$ is the electron potential energy density at the $\mathrm{BCP} .{ }^{[60]}$ It is well known that the values of electron density and its Laplacian can be used as a measure of the strength of the interaction. ${ }^{[61]}$ The strongest interactions are related to the highest values of electron density at the BCP. In accordance with the results reported in Table 3, the $\mathrm{N} 3-\mathrm{H} \cdots \mathrm{O} 1$ hydrogen bond is the strongest, with an interaction energy value of $-4.895 \mathrm{kcal} \mathrm{mol}^{-1}$ and seems to be responsible for the dimer formation. The self-assembled dimer in $\left[\mathrm{Cu}(\mathrm{DZP})_{2}\right]$ is also stabilised by a combination of weak hydrogen bonds $(\mathrm{C}-\mathrm{H} \cdots \mathrm{F})$ and $\mathrm{C}-\mathrm{H} \cdots \pi$ interactions. Based on results listed in Table 3, the $\mathrm{C} 10-\mathrm{H} 10 \mathrm{~B} \cdots \mathrm{F} 3 \mathrm{~A}$ interaction has

Table 3. Characteristics of the bond critical points (BCPs) of the intermolecular interactions in Cu-DZP $\rho$, electron density; $\nabla^{2}(\rho)$, Laplacian of the electron density; $G$, electron kinetic energy density; $H$, electron energy density; $V$, electron potential energy density; $E(\mathrm{H} \cdots \mathrm{A})$, interaction energy

\begin{tabular}{|c|c|c|c|c|c|c|c|}
\hline Interaction & $\mathrm{H} \cdots \mathrm{A}[\AA]$ & $\rho$ & $\nabla^{2}(\rho)$ & $\begin{array}{c}G \\
\text { [a.u.] }\end{array}$ & $\begin{array}{c}H \\
\text { [a.u.] }\end{array}$ & $\begin{array}{c}V \\
\text { [a.u.] }\end{array}$ & $\begin{array}{c}\mathrm{E}(\mathrm{H} \cdots \mathrm{A}) \\
{\left[\mathrm{kcal} \mathrm{mol}^{-1}\right]}\end{array}$ \\
\hline $\mathrm{N} 2-\mathrm{H} \cdots \mathrm{O} 1$ & 2.111 & 0.01880 & 0.06356 & 0.01527 & -0.00062 & -0.01589 & -4.895 \\
\hline $\mathrm{C} 4-\mathrm{H} 4 \cdots \mathrm{F} 1 \mathrm{~A}$ & 2.590 & 0.00536 & 0.02652 & 0.00538 & -0.00125 & -0.00663 & -2.081 \\
\hline $\mathrm{C} 10-\mathrm{H} 10 \mathrm{~B} \cdots \mathrm{F} 3 \mathrm{~A}$ & 2.660 & 0.00358 & 0.01955 & 0.00360 & -0.00129 & -0.00489 & -1.533 \\
\hline $\mathrm{C} 10-\mathrm{H} 10 \mathrm{~B} \cdots \mathrm{F} 2 \mathrm{~A}$ & 2.844 & 0.00491 & 0.02180 & 0.00444 & -0.00097 & -0.00540 & -1.696 \\
\hline $\mathrm{C} 10-\mathrm{H} 10 \mathrm{~A} \cdots \mathrm{Cg} 1$ & 3.047 & 0.00558 & 0.01800 & 0.00360 & -0.00090 & -0.00451 & -1.414 \\
\hline $\mathrm{C} 11-\mathrm{H} 11 \mathrm{~A} \cdots \mathrm{Cg} 2$ & 3.875 & 0.00305 & 0.00896 & 0.00176 & -0.00048 & -0.00224 & -0.703 \\
\hline H3 $\cdots \mathrm{H} 8$ & 2.863 & 0.00160 & 0.00628 & 0.00110 & -0.00047 & -0.00157 & -0.492 \\
\hline
\end{tabular}


a lower electron density and interaction energy than the C4-H4 ‥F1A.

AIM analysis was used to provide additional evidence for the existence of $\mathrm{C}-\mathrm{H} \cdots$ chelate ring (CR) interactions. Fig. S16 (Supplementary Material) shows the AIM plot of the $[\mathrm{Cu}-$ $(\mathrm{DZP})_{2}$ ] complex wherein it can be observed that each $\mathrm{C}-\mathrm{H} \cdots$ $\mathrm{CR}$ interaction between the chelate ring and the H10A from the DZP ring methylene group is characterised by a bond critical point that connects the $\mathrm{H} 10 \mathrm{~A}$ atom to the chelate ring carbon atom formed by $\mathrm{N} 1 / \mathrm{C} 7 / \mathrm{C} 1 / \mathrm{C} 2 / \mathrm{O} 1 / \mathrm{Cu}$ atoms, thus confirming the interaction. The high value of electron density and the interaction energy $\left(-1.414 \mathrm{kcal} \mathrm{mol}^{-1}\right)$ evidence that these interactions are stronger than conventional $\mathrm{C}-\mathrm{H} \cdots \pi$ interactions. These results are similar to those reported by Maity and co-workers. ${ }^{[29]}$ The supramolecular assembly of the complex is also governed by $\mathrm{C}-\mathrm{H} \cdots \pi$ interactions involving the centroid (Cg2) and the H11A from the methylene group of the diazepine ring and its existence was confirmed by AIM analysis with a $\mathrm{C} 11-\mathrm{H} 11 \mathrm{~A} \cdots \mathrm{Cg} 2$ interaction energy of $-0.703 \mathrm{kcal} \mathrm{mol}^{-1}$. In addition, there is a $\mathrm{H} 3 \cdots \mathrm{H} 8$ intermolecular interaction observed in the molecular pair $\left(E_{\mathrm{H} \cdots \mathrm{A}}=-0.492 \mathrm{kcal} \mathrm{mol}^{-1}\right)$ which also provides additional stabilisation of the crystal structure.

\section{Biological Activities \\ Inhibition of Growth and Biofilm Formation}

It is known that the formation of metal complexes can modify the activity of the ligand. In this work, the four complexes were tested against a model of Gram negative and Gram positive bacteria. The results showed that the antibacterial effect (growth inhibition) of the compounds against $\mathrm{Pseu}$ domonas aeruginosa $\mathrm{PAO} 1$ was less than $25 \%$ with respect to the growth control (Fig. 7). In general, Gram-negative bacteria are less sensitive to antimicrobials due to their external lipopolysaccharide membrane, which restricts the diffusion of hydrophobic compounds. ${ }^{[62]}$ In addition, P. aeruginosa has various active expulsion systems to eliminate antimicrobials that reach inside the microorganism. ${ }^{[63]}$

The antibiofilm properties were higher in $\left[\mathrm{Co}(\mathrm{DZP})_{2}(-\right.$ $\left.\left.\mathrm{H}_{2} \mathrm{O}\right)_{2}\right] \cdot 2 \mathrm{H}_{2} \mathrm{O},[\mathrm{Cu}(\mathrm{DZP})] \cdot 2 \mathrm{H}_{2} \mathrm{O}$, or $\left[\mathrm{Mn}(\mathrm{DZP})_{3}\right] \cdot 2 \mathrm{H}_{2} \mathrm{O}$ complexes compared with those observed for the free ligand (HDZP). In these cases, the antibiofilm activity was higher than the antimicrobial activity. The $\left[\mathrm{Mn}(\mathrm{DZP})_{3}\right] \cdot 2 \mathrm{H}_{2} \mathrm{O}$ complex produced the higher inhibition of the biofilm (40 and $31 \%$ ) at both concentrations of 100 and $10 \mu \mathrm{g} \mathrm{mL}^{-1}$, respectively (see Fig. 7).

With respect to the Gram positive bacteria, Staphylococcus aureus ATCC 6538, the presence of Co-DZP at $100 \mu \mathrm{g} \mathrm{mL}^{-1}$ inhibited $90 \%$ of the bacterial growth (Fig. 8). In order to determine the involved action mechanism, the MIC and MBC were determined. The MIC was $128 \mu \mathrm{g} \mathrm{mL}^{-1}$ and the $\mathrm{MBC}$ was $512 \mu \mathrm{g} \mathrm{mL}^{-1}$, indicating a good potentiality of the complex as an antimicrobial. These results are in concordance with recent studies that demonstrated the bactericidal property of metallosurfactants derived from cobalt oxide against several strains of Staphylococcus aureus. ${ }^{[64]}$ The author reported an important activity of several complexes present in nanoparticles at low concentration (near to $0.1 \mathrm{mM}$ ).

With respect to biofilm inhibition, it was higher than the growth inhibition in almost all complexes, with the exception of $\mathrm{Cu}$-DZP. In presence of $100 \mu \mathrm{g} \mathrm{mL}^{-1}$ of Ni-DZP, Mn-DZP, and Co-DZP, the $S$. aureus biofilm development decreased 30, 55, and $99 \%$ respectively. In addition, at $10 \mu \mathrm{g} \mathrm{mL}^{-1}$, Co-DZP inhibits $45 \%$ of the biofilm formation (Fig. 8).

In previous studies it was determined that the $\mathrm{Cu}^{2+}$ strongly influences the biofilm composition of $S$. aureus, in different ways, mainly by altering the structure of the exopolysaccharides that form the biofilm. ${ }^{[65]}$ The stress response to the complexes containing $\mathrm{Cu}^{\mathrm{II}}$ could be explained by the higher production of biofilm.

The increase in the biofilm production observed with $\mathrm{Mn}$-DZP at lower concentrations and with $\mathrm{Cu}$-DZP at lower and higher concentrations can be correlated with previous studies with several compounds against $S$. aureus. ${ }^{[66,67]}$ The increase in biofilm production might be part of a defence mechanism against the complexes. However, this mechanism is usually inefficient when the concentration is increased. ${ }^{[66,68]}$ In particular, copper interferes with exopolysaccharides altering the absorption bands and hence the composition, possibly increasing the biomass by stress.

It is well documented that the presence of free bivalent cations such as $\mathrm{Cu}^{\mathrm{II}}, \mathrm{Ni}^{\mathrm{II}}, \mathrm{Co}^{\mathrm{II}}$, or $\mathrm{Zn}^{\mathrm{II}}$ improves adhesion between biofilm cells. ${ }^{[69]}$ For this reason, a complex with a partial lipophilic character allows its insertion with the respective incorporated cations and interferes with the development and formation of the biofilm. Chohan and co-workers have

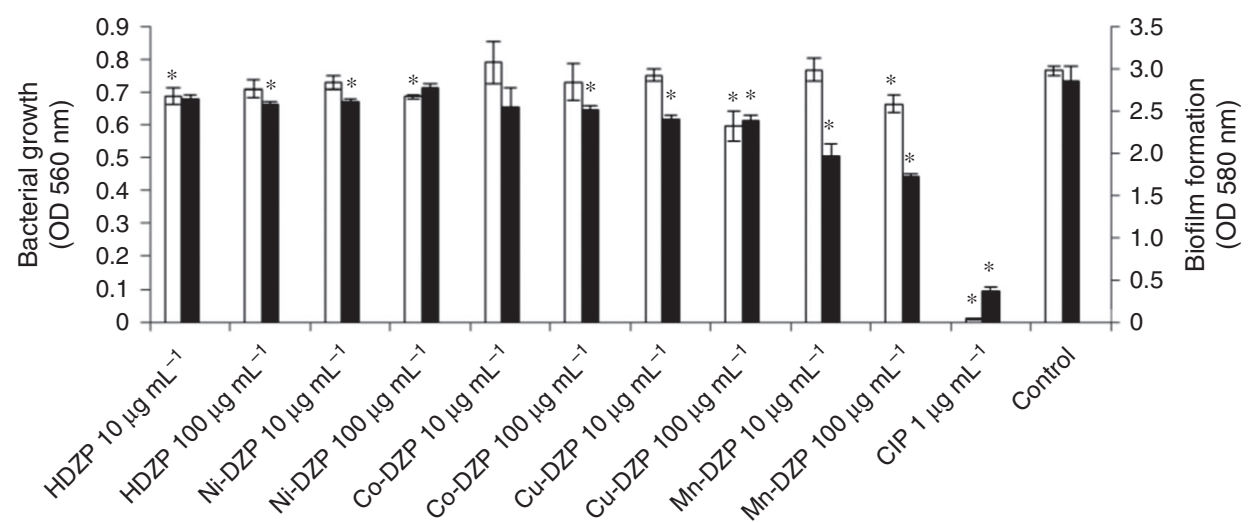

Fig. 7. Growth $(\square)$ and biofilm formation ( $\square)$ by P. aeruginosa PAO1 cultures grown in LB broth in absence and presence of 10 and $100 \mu \mathrm{g} / \mathrm{mL}$ of HDZP, [Ni(DZP $\left.)_{2}\right](\mathrm{Ni}-\mathrm{DZP}),\left[\mathrm{Co}(\mathrm{DZP})_{2}\left(\mathrm{H}_{2} \mathrm{O}\right)_{2}\right] \cdot 2 \mathrm{H}_{2} \mathrm{O}(\mathrm{Co}-\mathrm{DZP}),\left[\mathrm{Cu}(\mathrm{DZP})_{2}\right] \cdot 2 \mathrm{H}_{2} \mathrm{O}(\mathrm{Cu}-\mathrm{DZP})$, and $\left[\mathrm{Mn}(\mathrm{DZP})_{3}\right] \cdot 2 \mathrm{H}_{2} \mathrm{O}$ (Mn-DZP). The inhibitor control was CIP (Ciprofloxacin) $1.0 \mu \mathrm{g} \mathrm{mL}^{-1}$. The error bars indicate the standard deviation $(n=4)$. An asterisk was used to indicate significant differences $(P<0.05)$. 


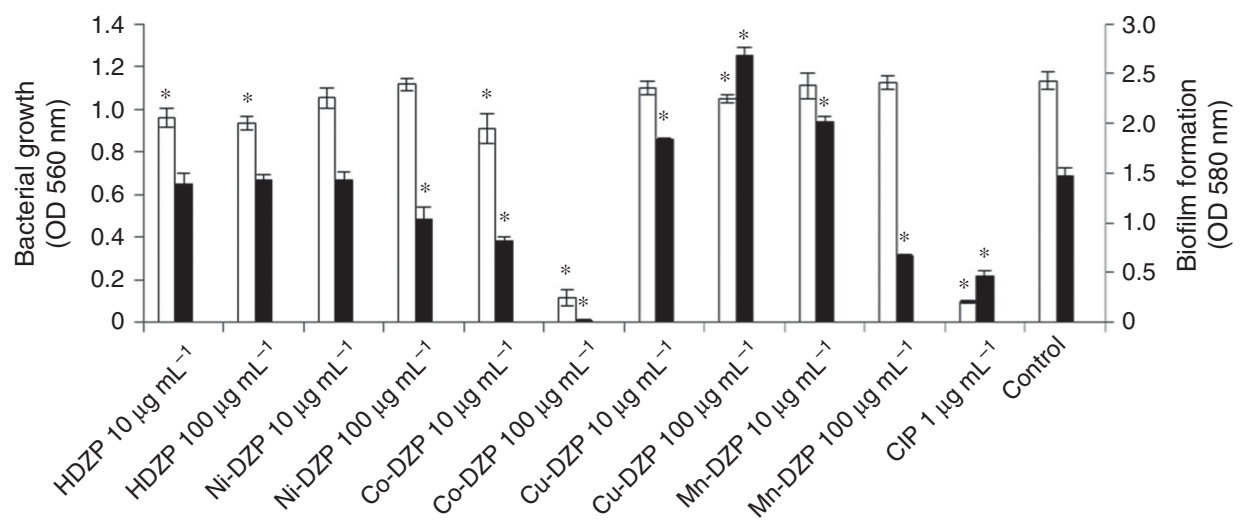

Fig. 8. Growth $(\square)$ and biofilm formation $(\square)$ by S. aureus ATCC 6538 cultures grown in MH broth in absence and presence of 10 and $100 \mu \mathrm{g} \mathrm{mL}^{-1}$ of HDZP, [Ni(DZP $\left.)_{2}\right](\mathrm{Ni}-\mathrm{DZP}),\left[\mathrm{Co}(\mathrm{DZP})_{2}\left(\mathrm{H}_{2} \mathrm{O}\right)_{2}\right] \cdot 2 \mathrm{H}_{2} \mathrm{O}(\mathrm{Co}-\mathrm{DZP}),\left[\mathrm{Cu}(\mathrm{DZP})_{2}\right] \cdot 2 \mathrm{H}_{2} \mathrm{O}(\mathrm{Cu}-\mathrm{DZP})$, and $\left[\mathrm{Mn}(\mathrm{DZP})_{3}\right] \cdot 2 \mathrm{H}_{2} \mathrm{O}(\mathrm{Mn}-\mathrm{DZP})$. The inhibitor control was CIP (Ciprofloxacin) $1.0 \mu \mathrm{g} \mathrm{mL}^{-1}$. The error bars indicate the standard deviation $(n=4)$. An asterisk was used to indicate significant differences $(P<0.05)$.

reported that the polarity of the metal complexes is generally lower than those of the ligands. This effect is related to the greater electron delocalisation which improves the lipophilic character with respect to the ligand. This electronic effect allows a better diffusion of complexes in the lipid membrane and therefore increases its biological activities. ${ }^{[70]}$ Previous studies also suggest that numerous metal chelates exhibit slightly higher antibacterial activity than free ligands. This effect is clearly explained by Overtone's concept and the Tweedy chelation theory. ${ }^{[71]}$ In addition, it is well known that some transition metals can act as active centres in bioactive molecules present in living systems.

According to the present results, $\left[\mathrm{Co}(\mathrm{DZP})_{2}\left(\mathrm{H}_{2} \mathrm{O}\right)_{2}\right] \cdot 2 \mathrm{H}_{2} \mathrm{O}$ is a good candidate to use against $S$. aureus, because this compound inhibits the microorganism growth and decreases significantly the main bacterial resistant mechanism, biofilm.

\section{Conclusions}

In this work, the synthesis, spectroscopic, and structural characterisation of metal complexes with (6Z)-6-(7-trifluoromethyl1,2,3,4-tetrahydro-5H-1,4-diazepin-5-ylidene)cyclohexa-2,4dien-1-one (HDZP) as ligand is reported. The crystal structure of the $\left[\mathrm{Cu}(\mathrm{DZP})_{2}\right]$ complex was determined by X-ray diffraction methods. The crystal packing of the complex is stabilised by classical $\mathrm{N}-\mathrm{H} \cdots \mathrm{O}$ hydrogen bonds and the solid state structure exhibits interesting chelate ring (CR)-H and $\mathrm{C}-\mathrm{H} \cdots \pi$ interactions. The nature of these intermolecular interactions has been studied through DFT calculations and Hirshfeld surface analysis. The results described herein might be useful to understand the solid state architecture of different organic-inorganic hybrid materials containing $\mathrm{Cu}^{\mathrm{II}}$-chelate rings and aromatic molecules as ligands. The growth inhibitory activity and anti-biofilm activity against $S$. aureus and $P$. aeruginosa were evaluated for the ligand HDZP and its metal complexes. The [Co$\left.(\mathrm{DZP})_{2}\left(\mathrm{H}_{2} \mathrm{O}\right)_{2}\right] \cdot 2 \mathrm{H}_{2} \mathrm{O}$ complex is a good candidate to use against Staphylococcus aureus since in its presence both bacterial growth and biofilm formation decreases significantly.

\section{Supplementary Material}

IR spectra of the ligand HDZP and its $\mathrm{Cu}^{\mathrm{II}}, \mathrm{Ni}^{\mathrm{II}}, \mathrm{Co}^{\mathrm{II}}$ and $\mathrm{Mn}^{\mathrm{III}}$ complexes (Figs S1-S4); electronic spectra of the complexes (Fig. S5); Hirshfeld surfaces mapped over shape index and curvedness properties (Figs S7 and S8); crystal packing of the
$\mathrm{Cu}^{\text {II }}$ complex (Figs S6, S9 and S10); TGA curves for the thermal decomposition of the complexes (Figs S11-S14); a proposed molecular structure of $\mathrm{Co}^{\mathrm{II}}$ and $\mathrm{Mn}^{\mathrm{III}}$ complexes (Fig. S15); distribution of bond critical points in a dimer of the $\mathrm{Cu}$ II complex (Fig. S16); vibrational data for the ligand and complexes (Table S1); absorption bands with the corresponding assignment (Table S2); and hydrogen bond geometrical parameters of the $\mathrm{Cu}^{\mathrm{II}}$ complex (Table S3) are available on the Journal's website.

\section{Conflicts of Interest}

The authors declare no conflicts of interest.

\section{Acknowledgements}

The authors thank CONICET (Grant PIP 11220130100651CO, PIP 0359), UNLP (Grants 11/X709, 11/X673, 11/X830, 11/X848), ANPCyT (PICT 2016-0226) and SCAIT (Project D639/2) for financial support. G.A.E., S.E. U., D.M.G., M.E.A, and O.E.P are research fellows and M.R. is a scholarship holder of CONICET. J.L.J is a research fellow of Comisión de Investigaciones Científicas de la Prov. de Buenos Aires (CIC).

\section{References}

[1] L. H. Sternbach, L. O. Randall, R. F. Banziger, H. Lehr, in Drugs Affecting the Central Nervous Systems (Eds A. Burger, M. Dekker) 1968, Medicinal Research Series, Vol. 2, pp. 237-264 (Marcel Dekker Inc.: New York, NY).

[2] N. A. Meanwell, M. A. Walker, in Comprehensive Heterocyclic Chemistry III (Eds A. R. Katritzky, C. A. Ramsden, E. F. V. Scriven, R. J. K. Taylor) 2008, pp. 183-235 (Elsevier Ltd: Oxford).

[3] J. H. Ryan, C. Hyland, J. Just, A. G. Meyer, J. A. Smith, C. C. Williams, in Progress in Heterocyclic Chemistry (Eds G. W. Gribble, J. A. Joule) 2013, pp. 455-495 (Elsevier BV: Amsterdam).

[4] G. A. Archer, L. E. O. H. Sternbach, Chem. Rev. 1968, 68, 747. doi:10. 1021/CR60256A004

[5] L. L. Brunton, B. A. Chabner, B. C. Knollmann (Eds), Goodman and Gilman's The Pharmacological Basis of Therapeutics, 12th edn 2011 (McGraw Hill Professional: New York, NY).

[6] R. Kumar, Y. Chandra Joshi, J. Chem. Sci. 2009, 121, 497. doi:10. 1007/S12039-009-0059-Y

[7] R. Kenchappa, Y. D. Bodke, S. Telkar, O. Nagaraja, Russ. J. Gen. Chem. 2017, 87, 2027. doi:10.1134/S1070363217090195

[8] J. S. Biradar, S. B. Somappa, Arab. J. Chem. 2016, 9, S1063. doi:10. 1016/J.ARABJC.2011.11.014

[9] E. A. Henderson, D. G. Alber, R. C. Baxter, S. K. Bithell, J. Budworth, M. C. Carter, A. Chubb, G. S. Cockerill, V. C. L. Dowdell, I. J. Fraser, R. A. Harris, S. J. Keegan, R. D. Kelsey, J. A. Lumley, J. N. Stables, 
N. Weerasekera, L. J. Wilson, K. L. Powell, J. Med. Chem. 2007, 50, 1685. doi:10.1021/JM060747L

[10] J. G. Ghogare, S. V. Bhandari, K. G. Bothara, A. R. Madgulkar, G. A. Parashar, B. G. Sonawane, P. R. Inamdar, Eur. J. Med. Chem. 2010, 45, 857. doi:10.1016/J.EJMECH.2009.09.014

[11] R. K. Gill, S. O. Kaushik, J. Chugh, S. Bansal, A. Shah, J. Bariwal, Mini Rev. Med. Chem. 2014, 14, 229. doi:10.2174 13895575113139990081

[12] G. M. Karp, M. C. Manfredi, M. A. Guaciaro, C. L. Ortlip, P. Marc, I. T. Szamosi, J. Agric. Food Chem. 1997, 45, 493. doi:10.1021/ JF960669I

[13] M. J. Kukla, H. J. Breslin, C. J. Diamond, P. P. Grous, C. Y. Ho, M. Miranda, J. D. Rodgers, R. G. Sherrill, E. De Clercq, R. Pauwels, K. Andries, L. J. Moens, M. A. C. Janssen, P. A. J. Janssen, J. Med. Chem. 1991, 34, 3187. doi:10.1021/JM00115A007

[14] N. Bennamane, R. Kaoua, L. Hammal, B. Nedjar-Kolli, Org. Commun. 2008, 1,62 .

[15] J. X. Xu, H. T. Wu, S. Jin, Chin. J. Chem. 1999, 17, 84. doi:10.1002 CJOC.19990170112

[16] K. Nabih, A. Baouid, A. Hasnaoui, A. Kenz, Synth. Commun. 2004, 34 , 3565. doi: $10.1081 /$ SCC-200031020

[17] R. I. Fryer, C. Cook, N. W. Gilman, A. Walser, Life Sci. 1986, 39, 1947. doi:10.1016/0024-3205(86)90318-8

[18] V. Venkatraj, R. Jeyaraman, Indian J. Chem. 2006, 45B, 1531.

[19] C. D. Alcívar León, G. A. Echeverría, O. E. Piro, S. E. Ulic, J. L. Jios, C. A. Luna Tapia, M. F. Mera Guzmán, Mol. Phys. 2019, 117, 368. doi:10.1080/00268976.2018.1514132

[20] M. C. Aversa, P. Bonaccorsi, M. Cusumano, P. Giannetto, D. Minniti, J. Chem. Soc., Dalton Trans. 1991, 3431. doi:10.1039/DT9910003431

[21] R. A. Peralta, A. Neves, A. J. Bortoluzzi, A. Casellato, A. dos Anjos, A. Greatti, F. R. Xavier, B. Szpoganicz, Inorg. Chem. 2005, 44, 7690. doi:10.1021/IC050755C

[22] S. Zhang, W. H. Sun, X. F. Kuang, I. Vystorop, J. J. Yi, J. Organomet Chem. 2007, 692, 5307. doi:10.1016/J.JORGANCHEM.2007. 08.020

[23] J. Romba, D. Kuppert, B. Morgenstern, C. Neis, S. Steinhauser, T. Weyhermüller, K. Hegetschweiler, Eur. J. Inorg. Chem. 2006, 314 doi:10.1002/EJIC.200500690

[24] G. Borkow, J. Gabbay, Curr. Med. Chem. 2005, 12, 2163. doi:10.2174/ 0929867054637617

[25] Q. Liu, R. Huo, D. Wei, X. Zhao, Z. Zhao, K. Cai, Dyes Pigments 2017, 139, 1. doi:10.1016/J.DYEPIG.2016.12.018

[26] P. Mahapatra, A. Bauzá, A. Frontera, M. G. B. Drew, A. Ghosh, Inorg. Chim. Acta 2018, 477, 89. doi:10.1016/J.ICA.2018.01.035

[27] M. K. Bhattacharyya, U. Saha, D. Dutta, A. Das, A. K. Verma, A. Frontera, RSC Adv. 2019, 9, 16339. doi:10.1039/C9RA01181A

[28] G. Mahmoudi, A. Bauzá, A. V. Gurbanov, F. I. Zubkov, W. Maniukiewicz, A. Rodríguez-Diéguez, E. López-Torres, A Frontera, CrystEngComm 2016, 18, 9056. doi:10.1039/C6CE02073A

[29] T. Maity, H. Mandal, A. Bauzá, B. C. Samanta, A. Frontera, S. K. Seth, New J. Chem. 2018, 42, 10202. doi:10.1039/C8NJ00747K

[30] M. Dzieciol, E. Schornsteiner, M. Muhterem-Uyar, B. Stessl, M. Wagner, S. Schmitz-Esser, Int. J. Food Microbiol. 2016, 223, 33. doi:10.1016/J.IJFOODMICRO.2016.02.004

[31] N. Høiby, T. Bjarnsholt, M. Givskov, S. Molin, O. Ciofu, Int. J. Antimicrob. Agents 2010, 35, 322. doi:10.1016/J.IJANTIMICAG. 2009.12.011

[32] M. Rocha, G. A. Echeverría, O. E. Piro, J. L. Jios, S. E. Ulic, D. M. Gil, J. Org. Chem. 2019, 84, 11042. doi:10.1021/ACS.JOC.9B01533

[33] V. Ya. Sosnovskikh, B. I. Usachev, Russ. Chem. Bull. 2001, 50, 1426. doi:10.1023/A:1012741224882

[34] CrysAlisPro, version 1.171.33.48 (release 15-09-2009 CrysAlis171. NET) 2009 (Oxford Diffraction Ltd: UK).

[35] G. M. Sheldrick, Acta Crystallogr. 2015, A71, 3 .

[36] G. M. Sheldrick, Acta Crystallogr. 2008, A64, 112. doi:10.1107/ S0108767307043930

[37] P. Van der Sluis, A. L. Spek, Acta Crystallogr. 1999, A46, 194.

[38] A. L. Spek, PLATON, A Multipurpose Crystallographic Tool 1998 (Utrecht University: Utrecht, The Netherlands).
[39] J. J. McKinnon, M. A. Spackman, A. S. Mitchell, Acta Crystallogr. 2004, B60, 627. doi: $10.1107 / \mathrm{S} 0108768104020300$

[40] J. J. McKinnon, D. Jayatilaka, M. A. Spackman, Chem. Commun 2007, 3814. doi: 10.1039/B704980C

[41] M. A. Spackman, D. Jayatilaka, CrystEngComm 2009, 11, 19. doi:10 1039/B818330A

[42] M. A. Spackman, Chem. Rev. 1992, 92, 1769. doi:10.1021/ CR00016A005

[43] M. J. Turner, J. J. McKinnon, S. K. Wolff, D. J. Grimwood, P. R. Spackman, D. Jayatilaka, M. A. Spackman, CrystalExplorer17 2017 (University of Western Australia: Perth).

[44] M. J. Frisch, G. W. Trucks, H. B. Schlegel, G. E. Scuseria, M. A. Robb, J. R. Cheeseman, G. Scalmani, V. Barone, B. Mennucci, G. A. Petersson, H. Nakatsuji, M. Caricato, X. Li, H. P. Hratchian, A. F. Izmaylov, J. Bloino, G. Zheng, J. L. Sonnenberg, M. Hada, M. Ehara, K. Toyota, R. Fukuda, J. Hasegawa, M. Ishida, T. Nakajima, Y. Honda, O. Kitao, H. Nakai, T. Vreven, J. A. Montgomery, Jr, J. E. Peralta, F. Ogliaro, M. Bearpark, J. J. Heyd, E. Brothers, K. N. Kudin, V. N. Staroverov, R. Kobayashi, J. Normand, K. Raghavachari, A. Rendell, J. C. Burant, S. S. Iyengar, J. Tomasi, M. Cossi, N. Rega, J. M. Millam, M. Klene, J. E. Knox, J. B. Cross, V. Bakken, C. Adamo, J. Jaramillo, R. Gomperts, R. E. Stratmann, O. Yazyev, A. J. Austin, R. Cammi, C. Pomelli, J. W. Ochterski, R. L. Martin, K. Morokuma, V. G. Zakrzewski, G. A. Voth, P. Salvador, J. J. Dannenberg, S. Dapprich, A. D. Daniels, Ö. Farkas, J. B. Foresman, J. V. Ortiz, J. Cioslowski, D. J. Fox, Gaussian 092009 (Gaussian, Inc.: Wallingford, CT).

[45] R. F. W. Bader, Atoms in Molecules: A Quantum Theory 1990 (Oxford University Press: Oxford)

[46] G. A. O'Toole, R. Kolter, Mol. Microbiol. 1998, 28, 449. doi:10.1046/ J.1365-2958.1998.00797.X

[47] J. E. Galván, M. E. Defonsi Lestard, O. E. Piro, G. Echeverría, R. D. I. Molina, M. E. Arena, S. E. Ulic, M. E. Tuttolomondo, A. Ben Altabef, New J. Chem. 2018, 42, 11073. doi:10.1039/C7NJ05138G

[48] CLSI, Methods for Dilution Antimicrobial Susceptibility Tests for Bacteria that Grow Aerobically (Approved Standard - Seventh Edition document M7-A7) 2006 (CLSI: Wayne, PA).

[49] R. Bikas, M. Emami, K. Slepokura, N. Noshiranzadeh, New J. Chem. 2017, 41, 9710. doi:10.1039/C7NJ01562C

[50] N. Kavitha, P. V. Anantha Lakshmi, J. Saudi Chem. Soc. 2017, 21 , S457. doi:10.1016/J.JSCS.2015.01.003

[51] K. Kavitha, M. Rama Chary, B. V. V. A. Singavarapu, K. Laxma Reddy, J. Saudi Chem. Soc. 2016, 20, 69. doi:10.1016/J.JSCS.2013. 03.005

[52] A. Dutta, S. Biswas, M. Dolai, B. K. Shaw, A. Mondal, S. K. Saha, M. Ali, RSC Adv. 2015, 5, 23855. doi:10.1039/C5RA00239G

[53] L. J. Farrugia, J. Appl. Cryst. 1997, 30, 565. doi:10.1107/ S0021889897003117

[54] M. Khorshidifard, H. Amiri Rudbari, Z. Kazemi-Delikani, V. Mirkhani, R. Azadbakht, J. Mol. Struct. 2015, 1081, 494. doi:10. 1016/J.MOLSTRUC.2014.10.071

[55] Z. Abbasi, M. Salehi, A. Khaleghian, M. Kubicki, J. Mol. Struct. 2018, 1173, 213. doi:10.1016/J.MOLSTRUC.2018.06.104

[56] N. Poulter, M. Donaldson, G. Mulley, L. Duque, N. Waterfield, A. G. Shard, S. Spencer, A. Tobias, A. Jenkins, A. L. Johnson, New J. Chem. 2011, 35, 1477. doi:10.1039/C1NJ20091G

[57] H. J. Schneider, Angew. Chem. Int. Ed. 2009, 48, 3924. doi:10.1002/ ANIE. 200802947

[58] L. M. Salonen, M. Ellermann, F. Diederich, Angew. Chem. Int. Ed. 2011, 50, 4808. doi:10.1002/ANIE.201007560

[59] S. Grimme, Chem. - Eur. J. 2012, 18, 9955. doi:10.1002/CHEM. 201200497

[60] E. Espinosa, E. Molins, C. Lacomte, Chem. Phys. Lett. 1998, 285, 170 doi:10.1016/S0009-2614(98)00036-0

[61] E. Espinosa, I. Alkorta, J. Elguero, E. Molins, Acta Crystallogr. 2004, 60A, s177. doi:10.1107/S0108767304096503

[62] S. Burt, Int. J. Food Microbiol. 2004, 94, 223. doi:10.1016/J. IJFOODMICRO.2004.03.022

[63] M. C. Fariñas, L. Martínez-Martínez, Enferm. Infecc. Microbiol. Clin. 2013, 31, 402. doi:10.1016/J.EIMC.2013.03.016 
[64] V. Dogra, G. Kaur, S. Jindal, R. Kumar, S. Kumar, N. Kumar Singhal, Sci. Total Environ. 2019, 681, 350. doi:10.1016/J.SCITOTENV.2019. 05.078

[65] D. Sun, D. Xu, C. Yang, J. Chen, M. B. Shahzad, Z. Sun, J. Zhao, T. Gu, K. Yang, G. Wang, Mater. Sci. Eng. 2016, C69, 744. doi:10.1016/J. MSEC.2016.07.050

[66] C. Socolsky, M. E. Arena, Y. Asakawa, A. Bardon, J. Nat. Prod. 2010, 73, 1751. doi:10.1021/NP1001779

[67] Z. A. Mirani, S. Naz, F. Khan, M. Aziz, M. N. Khan, S. I. Khan, J. Antibiot. 2017, 70, 115.
[68] K. K. Jefferson, FEMS Microbiol. Lett. 2004, 236, 163. doi:10.1111/J. 1574-6968.2004.TB09643.X

[69] T. Garrett, M. Bhakoo, Z. Zhang, Prog. Nat. Sci. 2008, 18, 1049. doi:10.1016/J.PNSC.2008.04.001

[70] Z. H. Chohan, M. Arif, M. A. Akhtar, C. T. Supuran, Bioinorg. Chem. Appl. 2006, 2006, 83131. doi:10.1155/BCA/2006/83131

[71] B. Mohan, A. Jana, N. Das, S. Bharti, M. Choudhary, J. Mol. Struct. 2018, 1171, 94. doi:10.1016/J.MOLSTRUC.2018.06.016 